\title{
An Historical and Critical Anlaysis of Interpleader
}

\author{
Geoffrey C. Hazard, Jr.* and Myron Moskovitz $\dagger$
}

The equitable remedy of interpleader ... depends upon and requires the existence of the four following elements, which may be regarded as its essential conditions: 1. The same thing, debt, or duty must be claimed by both or all the parties against whom the relief is demanded. 2. All their adverse titles or claims must be dependent, or be derived from the same source. 3 . The person asking the relief-the plaintiff-must not have nor claim any interest in the subject-matter. 4. He must have incurred no independent liability to either of the claimants; that is, he must stand perfectly indifferent between them, in the position merely of a stakeholder.

\section{Pomeroy, Equity Jurisprudence $§ 1322$ (1883)}

$\mathrm{T}$

HE ESSENTIAI IDEA of interpleader seems simple enough: A person confronted with conflicting demands that he do or pay something ought not to be hable twice. ${ }^{1}$ In medieval and renaissance England the typical case was that of a bailee holding chattels as security for the performance of a promise by one bailor to another and in doubt whether the promise had been performed, and therefore in doubt as to whom to make redelivery. ${ }^{2}$ In the nineteenth century the cases most typically arose out of commercial transactions, for example where a carrier, broker, or warehouseman found himself holding goods claimed on the one hand by a seller attempting to rescind and on the other by the creditors of a buyer who had become insolvent. ${ }^{3}$ Today, the standard case of interpleader is the insurance company confronted by rival claimants to the

* Professor of Law, University of Chicago; Administrator, American Bar Foundation. † LL.B., 1964, University of California, Berkeley.

1 See, e.g., 2 Storx, Equity JURTSpRUdence \& 806 (4th ed. 1846): "[T] of Courts of Equity, to compel an interpleader ... is properly applied to cases, where two or more persons severally claim the sanie thing ... from another person, who ... not knowing to which of the claimants he ought of right render the debt or duty claimed ... fears, that he may suffer injury from the conflicting claims of the parties."

Rule 22 of the Federal Rules of Civil Procedure, the most widely adopted current formulation of the interpleader rule, in principal part provides more austerely that: "Persons having claims against the plaintiff may be joined as defendants and required to interplead when their claims are such that the plaintiff is or may be exposed to double or inultiple liability."

2 See Rogers, Historical Origins of Interpleader, 51 YAIE L.J. 924 (1942).

3 See, e.g., Lowndes v. Cornford, 18 Ves. Jr. 299, 34 Eng. Rep. 330 (1811). 
proceeds of a life insurance policy. In each of these classes of cases the courts in their time have ordinarily provided a remedy, usually without much difficulty and often without much discussion.

If a procedural rule such as the one of interpleader had to answer only for a typical case, most discussions of the rule, and certamly this one, would be exercises. Yet life heaves up atypical situations, and from them stem atypical cases about which something has to be done. The issue then is not whether the rule is adequate for ordinary cases, but whether it is supple enough and precise enougl to afford fair guidance for disposition of the extraordinary case. Our place of beginning in this paper is the supposition that the traditional doctrines concerning interpleader are in a measure madequate in this sense. More particularly, we find two related weaknesses: First, the formulation of the conditions under which interpleader ouglit to be allowed is so indefinite as to beget confusion; second, partly because of this confusion, the contemporary judicial resolution of unusual interpleader situations is at times confounded by false doctrinal puzzles.

It should be said at once that most of the difficulties with interpleader from a practical point of view have been removed by legislation. There were, of course, a number of reforms in the nimeteenth century. ${ }^{5}$ And under the impetus of the indefatigable Zechariah Chafee, Jr. of the Harvard Law School, the Federal Interpleader Act ${ }^{6}$ and Rule 22 of the Federal Rules of Civil Procedure have made the remedy of interpleader easily available without procedural caviling in a broad range of cases. ${ }^{7}$ Nevertheless, there remain practical difficulties even in jurisdictions that have adopted the Federal Rules, for Rule 22, as we shall indicate, is indefinite in certain important respects. Those jurisdictions that retain the code version of interpleader still encounter many of the old troubles. Hence, some analytical work remains to be done, and we shall attempt it here. Moreover, these analytical problenis are aggravated in some nieasure by historical considerations. The first attempts at defimition of the interpleader reniedy occurred in precedents of the late eigliteenth and the early nineteenth centuries, precedents that manifest not only un-

4 The case best known is no doubt New York Life Ins. Co. v. Dunlevy, 241 U.S. 518 (1916).

5 E.g., Interpleader Act of 1831, I \& 2 Will. 4, c. 58; New York Code of Procedure $\S 122$ (1851). For the development of statutory provisions for interpleader with particular reference to New York, see Frumer, On Revising the New York Interpleader Statutes, 25 N.Y.U.L. REv. 737 (1950).

028 U.S.C. $\$ \S 1335,1397,2361$ (1958).

7 Chafee, Modernizing Interpleader, 30 YaLE L.J. 814 (1921), is the principal monograph. Others appear in 41 YAIE L.J. 1134 (1932); 42 YaIE L.J. 41 (1932); 45 YALE L.J. 963 (1936); 49 YaLe L.J. 377 (1940); 56 HaRv. L. Rev. 541 (1943); 56 HaRv. L. Rev. 929 (1943). 
appealing preferences in policy but plain lapses in systematic thought as well. Later law and present doctrine remain saddled with the burden of these cases. Our historical effort is intended to lighten that burden.

The argument in these pages is as follows: First, until the end of the eighteenth century there was no settled body of rules concerning the conditions under which interpleader might be available to a party who found himself confronted with competing claims. The course of the Court of Chancery consisted of an accepted tradition of practice and a few general precepts. The rules that came to be accepted in the nineteenth century as the rules of interpleader were developed in a dozen or so English decisions between 1790 and 1840 which upon reexamination look unconvincing.

Second, the expressions of opinion in the earlier English decisions were thereafter compressed into a black-letter mold that was at the same time simplistic and distorting. In part this process occurred in the developinent of doctrine in the nineteenth century cases. In part it occurred in the work of the text writers. Specifically, the four supposed "essential elements" for maintaining interpleader propounded by Pomeroy in his treatise, Equity Jurisprudence, ${ }^{8}$ are the product of uncritical reading and uncritical thinking. This process of compression appears in retrospect to be the consequence of the legal point of view, widely encountered in the nineteenth century, that combined a reverence for precedent with an insensitivity to the realities of history; all cases were read as though they were decided aright, and at about the same time. If it is recognized that the early cases were not all decided at the same time, and the assumption is indulged that judges in the past were as puzzled, as prone to rhetorical expedient and as occasionally slipshod as they are now, the precedents appear of less deterninate authority. Indeed, it seems not too much to say that one can advance as far by considering the problem of interpleader as an original proposition as by assuming that any part of the traditional doctrine of interpleader nuakes really good sense.

Third, and here we proceed analytically rather than historically, a satisfactory statement of the conditions under which interpleader ought to be allowed is no simple task. The approach that seems most effective, though perhaps not nost direct, is by a series of propositions which indicates that the strength of the interest in granting the man in the middle a way out of his dilemma is determined by the kind of dilemma he is in and how he got there. We shall undertake to state those propositions in the concluding portion of the paper. We begin with the historical account.

8 PoMerox, EQUTTY JURISPRUDENCE § 1322 (1883). 
INTERPLEADER BEFORE 1790

\section{A. Common Law Interpleader}

There was a common law remedy of interpleader that apparently found its widest use in the fourteenth and fifteenth centuries. The remedy was available to a defendant in a detinue action who was confronted with conflicting demands for possession of the chattel in question. It appears to have been the customary procedural device by which to determme whether promises secured by the deposit of chattels had in fact been performed. ${ }^{\circ}$ Though highly useful in its time and place, the remedy had a narrow range of application. It was circumscribed by the boundaries of detinue itself, and in time further confined because detinue ceased to be a generally used form of action. There are indications that interpleader nevertheless survived in the common law courts into the eighteenth century, ${ }^{10}$ but it appears to have become obsolete in the nineteenth. ${ }^{11}$

Common law interpleader seems to be doctrinally irrelevant to modern interpleader, the rules of which derive from the practice of the courts of equity, notably Chancery, in the eighteenth and nineteenth century. There is no evidence in the reports that common law interpleader had any direct shaping influence on the rules developed in equity. The tradition that equitable interpleader was influenced by the common law procedure depends on a casual observation by Story that "the jurisdiction of Courts of Equity, to compel an interpleader, follows, to some extent, the analogies of the law, "12 which in turn is supported by what seems to be an equally casual observation by Lord Hardwicke in $1749 .{ }^{13} \mathrm{Mr}$. Rogers

${ }^{0}$ See Rogers, supra note 2.

10 See Rich v. Aldred, 6 Mod. 216, 87 Eng. Rep. 968 (1704); Metcalf v. Hervey, 1 Ves. 248, 249, 27 Eng. Rep. 1011, 1012 (Ch. 1749).

11 See Second Report by the Coneminssioners into the Practice and Proceedings of the Supertor Courts of Compuon Law 24 (1830).

It appears that in the early part of the nineteenth century the most typical method of resolving simple conflicting claims to money or property was for the stakeholder to transfer the fund to one of the claimants pursuant to an indemnity agreement by which the transferee agreed to hold the stakeholder harmless from the claims of the other claimant. And it was said that the general utility of this method caused common law interpleader to sink into desuetude. See Pearson v. Cardon, 2 Russ. \& M. 606, 613, 39 Eng. Rep. 525, 528 (Ch. 1831) (Lord Brougham); cf. Burnett v. Anderson, 1 Mer. 405, 35 Eng. Rep. 723 (Ch. 1816), discussed at note 103 infra.

12 STORY, EQUTTY JURTSPRUDENCE $\$ 806$ (4th ed. 1846).

13 Metcalf v. Hervey, 1 Ves. 248, 249, 27 Eng. Rep. 1011, 1012 (Ch. 1749). In that case, discussed at greater length in the text accompanying note 48 infra, the plaintiff alleged that defendant had made a claim on him for the property of a decedent and that plaintiff was informed there was a more proper heir, the child of a certain Lady Hanmer. The question was whether so indefinite a claim, "founded on a rumour," was sufficient to justify an interpleader. Hardwicke observed: "[N] or should I be willing to allow new inventions in 
in his treatment of the development of the common law remedy has suggested that in it "were the historical origins of the modern bill of interpleader," 14 but the evidence he adduces consists mostly of cases "in Council" in the fourteenth and fifteenth centuries ${ }^{15}$ and a fragmentary report of a Chancery case from the time of Elizabeth $I^{10}$ There is no doubt that the central idea of interpleader and certainly the name of the proceeding where a stakeholder is confronted with inconsistent claims are the same in the old common law and in the newer equity. But only if one starts out with the firm conviction with respect to interpleader that "the history of our law is one of slow but gradual growth"17 can one emerge with that conclusion after a review of the available evidence. All things considered, we are confident of our belief that the contours of modern interpleader began to take shape no earlier than the late seventeenth century. ${ }^{18}$ Accordingly, that is our place of beginning.

\section{B. Lord Nottingham's Time}

Aside from the brief Elizabethan report already mentioned, ${ }^{10}$ the earliest Chancery case of whicl there is a report is also one of the most fully reported. This is Earl of Carlisle v. Goble (or Globe depending on the report).$^{20}$ The plaintiff had mortgaged land to Andrews, who then died. Plaintiff bemg in default, Andrews' heir at law, Mrs. Goble, obtained a decree of foreclosure. Thereafter, plaintiff discovered that Andrews left a will and an executor; he also apparently found funds to pay off the debt. Plaintiff brought suit contending that the heir had taken the land, but that the executor had the bond evidencing the debt; that the

bringing bills of interpleader; which might be dangerous; as they are formed in some measure as interpleader at law; in which it must be shown to be between persons in rerum natura."

14 Rogers, supra note 2, at 950 . See also id. at 949 n.109, 950 n.110.

15 It has been a habit for a long time to identify "the Council" of the late Plantagencts and the early Tudors as the nascent Court of Chancery. This usage is unexceptionable where loose reference is all that is intended, but it is a misleading anachronism if used to estabbish procedural or jurisdictional pedigrees. Cf. Jones, Conflict or Collaboration? Chancery Attitudes in the Reign of Elizabeth I, 5 AMr. J. LeGAx Hist. 12 (1961); Jones, Due Process and Slow Process in the Elizabethan Chancery, 6 Aar. J. LeGax Hrst. 123, 133-34, 147-50 (1962); Barnes, Due Process and Slow Process in the Late Elizabethan-Early Stuart Star Chamber, 6 AM. J. LEGaI Hist. 221, 315 (1962).

16 Alnete v. Bettam, Cary 65, 21 Eng. Rep. 25 (Ch. 1560).

17 Rogers, suppra note 2 , at $94 \%$.

18 This is indicated not only by the absence of evidence that Chancery borrowed its doctrine from the common law, but also by the absence of firm procedural doctrine in Chancery until the period mentioned. See Hazard, Indispensable Party: The Historical Origin of a Procedural Phantom, 61 CoLus. L. Rev. 1254, 1256 (1961).

19 See note 16 supra.

203 Ch. Rep. 94, 21 Eng. Rep. 739; Nels. 52, 21 Eng. Rep. 787; 2 Fr. 148, 22 Eng. Rep. 1121; 2 Eq. Cas. Abr. 173, 22 Eng. Rep. 148 (1659). 
executor was not a party to the redemption and not bound by the foreclosure decree; that plaintiff stood in jeopardy of being liable for the debt while having also lost the land; and that the previous foreclosure decree should therefore be set aside and plaintiff be allowed to redeem. The court ordered the mortgage and the bond brought in, thus protecting the plaintiff, and decreed that the land be sold and the proceeds interpleaded between the heir and the executor. This the court did without reported discussion of the procedure; in particular, there was no conjecturing about whether the heir and the executor were both claiming the "same thing"- - the land or the debt.

Other reported decisions from this period also concerned mortgagors faced with conflicting claims to redemption between leir and executor. ${ }^{21}$ One of these proceedings was referred to as "a Bill in the Nature of a Bill of Interpleader, ${ }^{\prime 22}$ a formula which was to be attributed significance in later years.

Hackett v. Webb, ${ }^{23}$ in 1676 , is the first reported decision by Lord Nottingham, the great Restoration Cliancellor. Hackett, in Ireland, had been directed by defendant Webb to try to collect a debt owed to Webb by Pitts. Pitts gave Hackett the sum of $£ 100$ and asked Hackett to adjust the accounts between himself and Webb, pay Webb the net due and return any balance. Hackett agreed to this arrangement and gave Pitts lis bond for $£ 100$ to secure faithful application of the fund. Pitts then died and Hackett found himself confronted with Webb's claim for the $£ 100$ and by a suit by Pitts' admimstrator on the bond. Interpleader was ordered:

The Court decreed an account, and in regard the Plaintiff had behaved himself well in this matter, it was ordered that his bond should be dehivered up to be cancelled, and a perpetual injunction [against the actions at law] as to him, and that his costs should be paid by such party as the court shall think fit, before the said $£ 100$ be taken out of court.

Hackett $v . W e b b$ is a precedent significant in several respects. For one thing, it involved an agent questioning the right of his primcipal to funds received by the agent. Indeed, Hackett had a dual agency and questioned both principals. It is important to note this well, for in a series of mineteenth century cases the supposed rule that an agent caimot challenge his principal was responsible for much confusion about interpleader.

21 Tilley v. Egerton, 2 Fr. 125, 22 Eng. Rep. 1102; 3 Ch. Rep. 63, 21 Eng. Rep. 729; 1 Ch. Rep. 181, 21 Eng. Rep. 543 (1660); Owen v. White, 2 Fr. 126, 22 Eng. Rep. 1102 (Ch. 1667); Shotbolt v. Biscow, 2 Eq. Cas. Abr. 173, 22 Eng. Rep. 148 (no date).

22 Shotbolt v. Biscow, supra note 21.

23 R. t. F. 257, 23 Eng. Rep. 141 (Ch. 1676). 
Hackett $v . W e b b$ also established the rule that a middleman who "had behaved himself" was entitled to costs, a rule that of course survives to this day. The case by implication suggests that a middleman who had not "behaved himself" could not get his costs of suit from the other parties to the dispute, which strikes the modern mind as also sensible. The case does not suggest, however, that a middleman who has not behaved himself, still less a middleman such as Hackett who had got into trouble by efforts that were well-intentioned, could not obtain interpleader. This point is emphasized because, again, the tolerant and business-like attitude of the court toward the middleman who has blundered contrasts so markedly with the moralizing indifference that appears in the decisions a century and half later.

The calm practical wisdom manifested by Chancellor Nottingham in Hackett v. Webb appears also in his notebooks, published under the editorship of Professor Yale. ${ }^{24}$ In these notebooks appear only four references to interpleader, but they are worth brief notice.

In Ferrar v. Bate, ${ }^{25}$ plaintiff brought a bill to compel the defendant to surrender up a bond which plaintiff executed in favor of defendant but which defendant allegedly held in trust for a third person, who plaintiff was apparently anxious to pay. Nottingham ordered that the third person be joined as an additional party, for as he observed:

[I] $t$ is a little to be wondered at why the plaintiff should so frankly and voluntarily pay the money [to the third person] without having the bond delivered up, since he could not have been compelled [to pay] without suit and then might have exhibited his bill of interpleader.

One may infer that the interpleader remedy in some form was generally recognized and routinely available in Nottingham's time, for Nottinghain was characteristically too circumspect and too practical to toss out suggestions of this sort unless they were well-founded in authority.

In Corderoy v. Carpenter, ${ }^{26}$ Nottingham disposed of an unusually complex controversy. Corderoy owed $£ 73$ to Swetman, evidenced by a note in that amount. Swetman assigned the note to Hord, in payment of a debt Swetman owed Hord. Carpenter, to whoin Swetman owed a substantial sum, then obtained an attachment against Corderoy, to reach the amount Corderoy owed Swetman. "The matter being thus intricated

\footnotetext{
24 Nottingham's Chancery Cases I, 73 Seld. Soc. (1957), and II, 79 Seld. Soc. (1961) (Yale ed.).

2579 Seld. Soc. 455 (No. 592) (1676).

2673 Seld. Soc. 232 (No. 343) (1675). The case is reported in R. t. F. 235, 23 Eng. Rep. 129, and under the name Corderoy's Case, in 1 Fr. 312, 22 Eng. Rep. 1233 (Ch. 1675). The report in R. temp. Finch is so incomplete as to be almost umintelligible, a shortcoming found not infrequently in the early reports.
} 
... ," Nottingham observed, "Corderoy by his bill desired he might pay the money but once ..." while "Carpenter by his bill prayed that the assignment to Hord, whereof he had no notice till after he was at the end of his [attachment] ... against Corderoy, might not now stand in his way to bar him the fruit of it."

Nottingham considered the bill on the merits, which is to say that he ascertamed the basis and strength of the competing claims and ranked them in order of priority:

I thought fit in this case to expose Corderoy to the danger of paying the money twice, for I saw that Carpenter had the law of his side against Corderoy, and he had equity also not to lose his money by an assignment whereof Corderoy gave him no notice during all the proceedings. ... Yet I decreed Carpenter to assign to Corderoy [his claim against Carpenter] which was little worth, Swetman being poor. ${ }^{27}$

Two points should be observed. First, Nottingham apparently took jurisdiction of the bill on the strength of the dilemma as it was related by the plaintiff stakeholder. He did not attempt to peep around the bill or to wait for the defendants' contentions to decide whether the plaintiff had acted with such a degree of punctilio and prescience as to deserve extrication from his quandary. This is worth emphasizing because there was a strong tendency in later cases to try to decide whether the case was properly one for interpleader by deciding the meritoriousness of the claims that had been interpleaded. Second, a decree was entered on the merits even though it appeared that on principles of estoppel the plaintiff could not be absolved from double liability. The decree therefore disposed of the case, rather than merely postponing the decision whether plaintiff was liable to both claimants. Beyond achieving a procedural economy, the issuance of the decree by implication establishes that Nottinghain could see no objection to an interpleader by a stakeholder who had an "independent liability," here liability based on estoppel, to one of the claimants. Such a liability in his view was relevant to the disposition, but not to the propriety of taking the case in the first place.

Another of Nottingham's notebook cases, Brown v. Tattershall,28 displays the same point of view in reaching a different result. Plaintiff borrowed money from an attorney, Thornton, the loan made from funds supplied by Tattershall. ${ }^{2 \theta}$ Plaintiff repaid Thornton without getting back

2773 Seld. Soc. at 233.

2873 Seld. Soc. 110 (No. 167) (1674).

29 The attorney probably was acting on a more or less regular basis as a loan broker. This was an important line of activity for attorneys before the development of an organized country banking system. See Robson, The AtToRney IN 18TH CENTURY EnNoLAND 115-18 (1959). 
the bond. Thornton absconded and plaintiff was then sued on the bond by Tattershall. Plaintiff souglit relief from Tattershall's suit so that he would not have to pay twice. Nottingham held:

I dismissed [the bill] . . , for though it were a hard case yet Tattershall is in no Fault ..., seeing he kept the bond which is all that any man hiving could do to prevent mispayment. [T] he keeping or not keeping the bond was the rule to judge whether the [attorney was or was not] not trusted with receipt of the money.

Another interpleader case that appears im Nottingham's notebook is Handford v. Lloyd. ${ }^{30}$ This was a bill by the tenant of a house who showed that he had rented a house from Sir Francis Lloyd; that Sir Francis's wife had disputed the propriety of the lease, contending that the house was hers by virtue of a marriage settleinent; that in consequence of the dispute between Sir Francis and his wife it was agreed that plaintiff should pay the rent to her; that Sir Francis thereafter died whereupon the title to the property had come into dispute between the widow and Sir Francis's son; that plaintiff had been sued at law for the rent by the son, and was in doubt as to whom to pay. Plaintiff prayed for an injunction against the proceedings at law. Nottingham observed that "the bill was in the nature of a bill of interpleader" and proceeded to hold on the merits for the widow.

Two observations should be made concerning this case also. First, it was a suit by a tenant against two persons claiming to be landlord. This business of a tenant questioning his landlord's title became central in later development of interpleader rules; in Nottingham's time it did not even beget discussion. And second, the case did not concern claims to anything that can easily be characterized as a fund, for there was no cash on plaintiff's hands, nor can it be referred to accurately as a "debt," for the rents coming due from plaintiff were not yet a debt to anyone. The case was therefore at least two steps away from the classic model of a bailee holding a tangible chattel.

It might be added that although Nottingham had on a couple of occasions referred to the suits as "bills in the nature of interpleader," it seems quite evident that this was not a technical term of art but merely a casual reference to the fact that the suit was like an interpleader at law. A bill in equity did not bear a label as to type, "interpleader" or otherwise. A bill by a middleman therefore would in all formal respects look and sound bke any other kind of bill seeking rehef quia timet. ${ }^{\text {a1 }}$ Notting-

3073 Seld. Soc. 349 (No. 491) (1676).

31 Relief quic timet ("because he fears") indeed is theoretically the raison d'être of equity. Cf. Borceard, Dectaratory Judgments 6 (2d ed. 1941). Procedurally, the key is the routine application for and grant of an injunction to stay proceedings at law against the interpleading plaintiff. 
ham was only saying that where the plaintiff was a middleman in a quandary as to whom to pay, and sought an injunction to stay suits against him, the suit resembled common law interpleader, which, of course, it did.

These are all the interpleader cases before 1738 of which a publislied record exists, barring a couple that involve now obsolete points of procedure concerning revivor and affidavits. ${ }^{32}$ Indeed, the virtually entire absence of reported interpleader cases for a period of a half century suggests either that no new wrinkles had unfolded to require comment or that the loose form of interpleader rnles as they then stood were adequate to the tasks of the day. In any event it would not have been inaccurate, though it would have been an oversimplification, to summarize the inid-eighteenth century rule of interpleader in the words of the rule of mid-twentieth: "Persons ... may be ... required to interplead when their claims are sucl that the plaintiff is or may be exposed to double or inultiple liability." ${ }^{\prime 33}$

Indeed, the treatises of the time said little more on the subject. The Practical Register in Chancery, published in 1714, stated:

[A] Bill of Interpleader, is a Bill exhibited by a Third Person, who not knowing to whom he ought of Right to render a Debt or Duty, fears he may be hurt by some of the Claimants; and therefore prays they may Interplead, so that the Court may adjudge to whom the Thing belongs, and he be made safe. ${ }^{34}$

The same passage appeared substantially verbatim in Bohun's Cursus Cancellariae in $1723 .^{35}$ In the succeeding paragraph of both treatises it was added that interpleader may be brought by one "who has suits at law brought agamst him, or is in danger of trouble from both the claimants." ${ }^{36}$

32 Anon., 1 Vern. 351, 23 Eng. Rep. 516 (Ch. 1685); Errington v. Attorney General, Bunb. 303, 145 Eng. Rep. 682 (Ex. 1731).

33 FED. R. Civ. P. 22.

34 Practical Register in Chancert 78 (Wyatt ed. 1800).

35 Bohun, Cursus Cancellariae 458 (2d ed. 1723). The earher Chancery practice book by Browne, published in 1694-95, has not been referred to previously, for it is too fragmentary to be of much interest. See Hazard, supra note 18, at 1262-63.

36 The paragraph in full reads: "Sometimes a Bill of Enterpleader is where one, who is not Party in the first Suit, supposes he has a separate Interest in the Matter in Question, and commences his Suit against the first Defendant, praying to be reheved according to his Right: Whereupon the first Plaintiff makes the second a Defendant, in Order to enterplead and contest the Rigbt: Or, if the first Plaintiff does not make him a Defendant, then the Defendant may exhibit his Bill against both Plaintiffs, and pray they may enterplead, and try to which of them the Thing in Demand belongs, and further, as his Case requires. Or, if there be no Suit here between the Pretenders, he, who has Suits at Law brought against him, or is in Danger of Trouble from both the Claimants, may file his Bill against them, and pray that they may enterplead, and that the Proceedings at Law against him may stay till the Right be determined." Bohun, Cursus Cancerrartae 458 (1723). 
A less elaborate description of interpleader cast in similar terms appeared in Equity Cases Abridged. ${ }^{37}$

Joseph Harrison's Chancery Practiser, first published in 1741 and followed by many subsequent editions, adopted the statement in the Practical Register without material change, ${ }^{38}$ indicating that doctrine had pretty well stabilized during the first half of the eighteenth century in the formula quoted above. ${ }^{39}$ Gilbert's Forum Romanum, preoccupied with assimilating the Court of Chancery to a suppositious Roman counterpart, said less, rather than inore, than the earlier treatises about the law of interpleader. ${ }^{40}$ Nothing it contains is relevant to the propositions that have been advanced.

\section{Lord Hardwicke's Time}

The comfortably imprecise general formula for interpleader that had thus been handed down received its first stiffening in two decisions by

371 Eq. Cas. Abr. 80, 21 Eng. Rep. 893; 2 Eq. Cas. Abr. 173, 22 Eng. Rep. 148.

38 Harrison's significant departures from the Practical Register and Bohun were two additional statements: (1) Interpleader might be brought by a person "who not knowing to whom he ought of Right to render a Debt or Duty, or pay his Rent, fears ...," perhaps reflecting the unreported decision in Handford v. Lloyd, supra note 30; (2) With reference to costs of suit, the statement that "if a Cause has been heard upon a Bill of Interpleader, and a Trial at Law directed to settle the Right between the Defendants, there is an End of the Suit, as to the Plaintiff." 1 Harrison, Chancery Practiser 232, 234 (1745 ed.).

The reference to jury trial is based on the decision in Anon., 1 Vern. 351-52, 23 Eng. Rep. 516 (Ch. 1685), cited also in 1 Eq. Cas. Abr. 80, 21 Eng. Rep. 893, and is a plain indication that, at least until the mid-eighteenth century, Chancery continued the practice of remanding contested issues of fact to the common law courts for trial to a jury, a practice that dated certainly from the time of Elizabeth and most probably back to the late medieval times. See Earl of Thanet v. Paterson, 3 Barn. 247, 252-54, 27 Eng. Rep. 632, 634 (1738), discussed at text accompanying note 41 , infra. Cf. Jones, Introduction to Petty Bag Proceedings in the Reign of Elizabeth I, 51 CALIF. L. REv. 882, 887 (1963). Nothing in the reports reveals a disturbance of this procedure until East India Co. v. Bazett, Jac. 91, 93, 37 Eng. Rep. 784, 785 (Ch. 1821), when Lord Eldon had occasion to say that the Chancellor was not bound to accept the jury's verdict on a motion for a new trial: "There is this difference between a motion for a new trial in a court of law and in a court of equity. In a court of law, if the jury find the fact, although the judge may tbink differently, yet it is permitted to stand, for the finding the fact is the province of the jury; but here the verdict is something more than the verdict of the jury; it must be such as to satisfy the Court, that it can make that its own declaration of the fact, which the jury have made theirs."

The relevance of this practice, to say nothing of the interesting nuances of Eldon's disquisition, seems not to have been appreciated in the determination of the proper scope of the right to jury trial under the sixth amendment to the Constitution. Cf. Beacon Theatres, Inc. v. Westover, 359 U.S. 500 (1959); Note, 47 CALIF. L. Rev. 760 (1959).

${ }^{39}$ The hberal appropriation of predecessor material is characteristic of practice books, and probably legal trcatises generally, throughout the time of Story and perhaps beyond. Its unseemliness according to present conceptions of hiterary property does not diminish its utility as a means of charting the course of doctrinal change.

40 Girbert, Forum Romanum, in The History and Practice of the Hrge Court or ChanCery 47 (1758). 
Chancellor Hardwicke in the middle of the century. These decisions restricted the scope of interpleader to some degree and in time became precedents for more drastic restriction. And there is no gainsaying that Hardwicke's complacent preference for justice over mercy shows through these opinions. Nevertheless, the restrictions he advanced are intelligible in logic and policy even according to present hghts; indeed, taken no further than he took thein they seem necessary precautions against gratuitous litigation by vexatious or timorous middlemen.

The first case, Earl of Thanet $v$. Paterson, ${ }^{41}$ was decided in 1738 , and it is important to note this fact. The case concerned a landlord and a tenant. At the time it was heard, Parliament, with whose affairs Hardwicke as Chancellor was intimately familiar, had just enacted the Landlord and Tenant Act of 1738, designed to remove procedural obstacles from the path of landlords attempting to collect rents. ${ }^{42}$ It seems evident from the report that Harwicke had the general problem very much on lis mind.

In the Paterson case, the plamtiff brouglit a bill agamst copyholders of his manor to collect fines (monetary inulct owing as an incident of copyliold tenure) that had allegedly come due on the death of plaintiff's father. The defendant tenants sought to interpose a cross-bill bringing in persons, apparently plaintiff's half-sisters, who allegedly claimed title to the manor by prior settleinent from plaintiff's father. Objection to the propriety of the tenants' maintaining the cross-bill was sustained on two grounds. ${ }^{43}$ First, it being undisputed that the plaintiff had been in possession of the manor since his father's death, he was clearly entitled to receive the fines so that the tenants upon payment of the fines to plaintiff "could not be bound to pay them over again" to one who, however good his title, did not have possession. That is to say, since as a matter of property law the obligation was dischargeable by payment to the person in possession, to whom the rightful owner would have to look for reimbursement, it followed that there could be no interpleader because there was no risk of "hurt," no danger from wlich the copyholders need "be made safe."

413 Barn. 247, 27 Eng. Rep. 632 (1738).

42 See discussion at text accompanying notes 82-89 infra.

$43 \mathrm{~A}$ further ground of objection was that the tenants had failed to pay the disputed fines into court. This was disposed of by a ruling that the interpleading party need only offer to pay the fund into court and must actually make deposit only if the other party so demands.

44 This analysis is confirmed by the discussion of Earl of Thanet v. Paterson in Langston v. Boylston, 2 Ves. Jr. 101, 108-09, 30 Eng. Rep. 543, 547 (Ch. 1793): "That [case] was in no respect a bill of interpleader. There could be no question, that the payment of the fine, assessed upon a copyhold or customary estate, to a lord in possession of the manor would discharge the tenant. He was the only person, to whom it could be paid. If there was another lord, with a title paramount, he might have recovered the fine against the lord, but 
of Manors] . . , if because a Title is set up by another, the Right which they have to Fines from their Tenants must be delayed, and they must go through the Course of an interpleading Bill." ${ }^{245}$ This is a formidable objection indeed, and it is worthwhile to explore its potential dimensions.

This was not a holding-not even an intimation-that a tenant might never question his landlord's title. A century later a proposition just that bald had gained adherence, largely on the strength of cases referring to the Landlord and Tenant Act of $1738 .^{40}$ Yet in the very year of the Act's adoption in a case susceptible to its application by a judge not indisposed to do so, no sucl broad proposition was asserted. On the contrary it was only suggested that it would be "difficult" if title were set up by another, i.e., if the tenant of his own initiative pointed to a rival claimant to his landlord's title. This leaves it entirely open what should be done if a tenant were faced with a real risk of double liability by a rival setting up his own title. ${ }^{47}$ Moreover, the discussion concerned a customary obligation by a copyhold tenant. The medieval tradition sustaining the sanctity of that sort of tenancy obligation would not necessarily support the obligation of a conventional tenant of the modern era. And finally, taking the case for the most that it could say, if in the higher political wisdom of the age of George II the interests of copyhold tenants were to be sacrificed to the interests of landlords in collecting their dues swiftly, surely no general procedural principle was laid down concerning the availability of interpleader to the stakeholders of a later day. Yet simpleminded precedent mongering, of which there was much after the turn of the eighteenth century, could yield such a principle.

With all these qualifications, however, it is a plain fact that the Earl of Thanet v. Paterson laid down that at least some persons "not knowing to whom [they] ought of right to render a debt or duty" could no longer get the Chancellor to relieve them of their fears. The ground given, that the claimants against the stakeholder would be inconvenienced by dilatory suits, recurs in the history of interpleader. It is one of those nice reasons that resolves a dilemma by referring to only one of its horns, for to allow a legal remedy to any class of potential hitigants is to run the risk that the causes of some will lack merit. To withhold the remedy if it might be abused is to compress it within the bounds of futility. There is no indication that Hardwicke intended or achieved that consequence,

not against the tenant. . . . If the two lords had both assessed him, which was impossible, that might have brought it to the case."

453 Barn. at 251, 27 Eng. Rep. at 633.

40 Principally Dungey v. Angove, 2 Ves. Jr. 304, 30 Eng. Rep. 644 (Ch. 1794), discussed at text accompanying note 68 infra.

47 Hardwicke noted that the rival claimants "never thought proper to pursue their claim to this very Day." 3 Barn. at 250, 27 Eng. Rep. at 633 . 
but, as we shall see, his successors in time very nearly did so. Earl of Thanet v. Paterson in any event did establish that interpleader may not be brought where the supposedly conflicting claim is so mamifestly insubstantial as to render the conflict imaginary, a principle implicit in the very concept of interpleader and well accepted to this day.

Hardwicke's second interpleader decision was Metcalf v. Hervey, in $1749,{ }^{48}$ and also concerned a tenant and his landlord. Plaintiff, in possession of lands under a demise, was sued in ejectment and for mesne profits by a third party claiming title to the lands. Plaintiff thereupon brought the present suit, "founded on a rumour, that there was issue by Lady Hanmer, which was suggested to be entitled to the estate in question; and praying that if there was any such person, he might interplead with the defendant"; and seeking discovery of the basis of his landlord's title. Defendant demurred on the general ground that no proper case for the intervention of equity was shown. The demurrer was overruled, but to the company of interesting dicta.

First, Hardwicke mused about whether interpleader could be brought against a claimant, the rumored issue of Lady Haniner, who was not identified. In this regard, the Clancellor said: " $[N]$ or should I be willing to allow new inventions in bringing bills of interpleader; which might be dangerous; as they are formed in some ineasure as interpleader at law; in which it must be shewn to be between persons in rerum natura [real, existing persons]. ${ }^{349}$ It might be noted that for Hardwicke, not merely in bills of interpleader but in general, new inventions were dangerous, and it is not surprising to see him balky at the prospect. Equally interesting is his half-hearted suggestion that equitable interpleader bills "are formed in some measure as interpleader at law," as a reason for denying interpleader against an indeterminate claimant. "Formed in some measure" could mean anything; in context it would seem to mean that so far as Hardwicke was concerned the era of flexibility in interpleader proceedings was being drawn to a close.

Second, Hardwicke stated that there could be no interpleader as to ejectment "as such a bill caunot be as to the possession, but must be as to the payment . . of money." In this observation may he the kernel of the subsequently developed notion that there can be no interpleader unless the claimants lay coextensive claims to a fund or an object of property; that is, interpleader will not lie where one claimant seeks an object of property and the other seeks compensatory damages for the taking of the object, inasmuch as in such a situation the claims are not

481 Ves. 248, 27 Eng. Rep. 1011 (Ch. 1749).

481 Ves. at 249, 27 Eng. Rep. at 1012.

50 Ibid. 
to "the same thing." a broad abstraction, for at that time ejectment, strictly speaking, was an action to determine not ownership but only possession. Since a claim for damages to property ordinarily at least had to be predicated on the claimant's ownership, in a technical sense a claim for damages and a claim for possession, as in ejectment, were not reciprocally dependent. Put another way, it is possible conceptually for a tenant on the one hand to have to surrender possession to a claimant who, while not the owner, nevertheless has a right sufficient to obtain possession, and on the other hand to have to yield legal title or to pay compensatory damages to the real owner. Indeed, theoretically this analysis is required with respect to an ejectment proceeding, for-again theoretically-it concerned only possession. And because ejectment and damages were not reciprocal, they were not susceptible of the conflict of claim required for an interpleader.

All this is pretty fine spun, but if Hardwicke is taken as following a coarser thread of reasoning, i.e., there could be no interpleader where one claim was for an object and the other claim was a demand for money, he was simply wrong. Earl of Carlisle v. Goble $e^{52}$ had involved such an interpleader and no subsequent case had cast doubt on it. It is difficult to believe that Hardwicke could have been so egregiously mistaken. But it must be recognized that his statement that interpleader "must be as to the payment of some demand of money" suggests that interpleader lies only where both claimants seek money, and is not available to the stakeholder if one of the claimants seeks money while the other seeks the object of property itself. ${ }^{53}$ If so, Hardwicke was the first of the Chancellors to lose sight of the fact that the basis for equitable jurisdiction in interpleader was not the identity of the conflicting claims' formulation but the fact that one who had "behaved himself well"s4 should not "be hurt by some of the claimants." statement was dictum and made no apparent inroads in the mam body

51 See text accompanying note 93 infra.

523 Ch. Rep. 94, 21 Eng. Rep. 739 (1659). For discussion of the case see text accompanying note 20 supra. See also Owen v. White, 2 Fr. 126, 22 Eng. Rep. 1102 (Ch. 1667).

53 It would seem that Hackett v. Webb, R. t. F. 257, 33 Eng. Rep. 141 (Ch. 1676), discussed at text accompanying note 23, supra, also involved claims respectively to money and to property. One claim was for money had and received by the middleman as agent for one of the claimants (which itself can be thought of as a claim to a "thing"), while the other claim was predicated on a bond. A bonded obligation is as close as a claim can come to being a thing as legal abstraction can get. Surcly the ease with which it is possible to make the conceptual passage from "thing" to "claim" and back again should be adequate warning against adopting either concept as a procedural predicate.

54 Hackett v. Webb, supra note 53.

55 The Practical Register in Cliancery, quoted at text accompanying note 34 supra. 
of interpleader rules as understood until that time. ${ }^{58}$ The rules remained general and in this sense liberal.

II

INTERPLEADER AFTER 1790

\section{A. Prelude to Abstraction}

The limiting of interpleader began in the last decade of the eighteenth century and culminated in 1837 with the case of Crawshay v. Thornton. It is well to keep in mind that this period, from the Revolution in France to the begimings of Reform, saw the whole English court system and especially the Court of Chancery, sink into the quagmire of administrative stagnancy and doctrinal conceit that Dickens could lampoon by describing. ${ }^{57}$ Unless the secular trend is kept in mind, the fascination with doctrinal artifice that cliaracterizes the disposition of interpleader problems in this period becomes not merely implausible but incomprehensible.

Our focus is on the reported cases, of which there was suddenly a much larger number. But it will be a helpful preface to notice the description of interpleader that appears in the edition of Mitford's Treatise on Chancery Pleadings published at the threshold of the historical period under review:

Where two or more persons claim the same thing by different or separate interests, and another person, not knowing to which of the claimants he ought of right to render a debt or duty or to deliver property in his custody, fears he may be hurt by them, he may exhibit a bill of interpleader against them. In this bill he must state his own rights, and their several claims ... so that the court may adjudge to whom the thing belongs....

56 This conclusion is based on the following facts: (1) After Metcalf v. Hervey in 1749 there are no reported interpleader decisions until Aldridge v. Thompson in 1787, 2 Bro. C. C. 149, 29 Eng. Rep. 85, at text accompanying note 60, infra; (2) Harrison's text on interpleader, see note 38 supra, went through several editions without the alterations that likely would have been made if Earl of Thanet v. Paterson and Metcalf v. Hervey had been applied as restrictively as their dicta would admit; and (3) Mrrrord, Treatrse on THE Pleadings in Sutrs in the Court of Chancery by English BIII 17 (1st ed. 1784), retiterates the statements of the earlier treatises without material change. But it is possible that Hardivicke's dicta brought the use of interpleader to an abrupt halt and that only after the lapse of forty years were there efforts to employ it again. The facts of the matter could only be resolved by systematic examination of the original papers in the Public Record Office, which no one has yet undertaken for the eighteenth century Chancery. In the history of procedural doctrine, which is of course what was transmitted to this country and with which this paper is concerned, the point is largely moot, and we leave it so.

67 Notably in BLEAK House. See generally Christopher, Progress in the Administration of Justice During the Victorian Period, 1 Select Essays IN Anglo-American Legal HistoRX 516 (1907). 
It has been mentioned that where two or more persons claim the same thing by different titles, and another person is in danger of injury from ignorance of the real title to the subject in dispute, courts of equity will assume a jurisdiction to protect him. ... 88 [Emphasis added.]

We have italicized the terms that refer to the "thing" being submitted to interpleader. The frequency of these references and their pivotal, indeed, definitional, position in the passages quoted, without shifting literal ineaning from earlier treatnients manifest what seems to be a clear shift in the conception of interpleader. ${ }^{59}$ Whereas interpleader had been thought of as a means of extricating a person in the middle of a three-cornered fight that was wholly or largely none of his concern, it was now thouglit of as a sort of quiet-title suit initiated by one who happened to have come into possession of property not his own. The original inodel of interpleader had been built around the man in a quandary; the new model centers on an object of disputation. Surely this change in frame of reference invited novel tests for the propriety of an interpleader proceeding. Concepts do not decide cases. They can, however, pose the question to be decided, which is of course even more important, and it may be that the interpleader formulation in Milford's treatise thus helped usher in the new doctrines.

A few of the cases early in the period are worth attention for what they did not say. Aldridge v. Thompson ${ }^{60}$ was a suit by a tenant whose rent obligation had been nuade the subject of annuities granted by the owner of the fee. There were several annuitants wlose claims apparently overlapped and whom the plaimtiff therefore interpleaded. A decree was entered on the merits without discussion, the report being concerned only with allocation of costs, even though it could have been said that in some sense the tenant was disputing the title of his landlord. ${ }^{01}$ Dowson $v$.

58 Mitrord, A Treatise on the Pleadings in Sutts in the Court of Chancery uy English BIIL 47-48, 125 (2d ed. 1789).

59 Contrast the language in Hackett $v$. Webb, at text following note 23 supra, in Corderoy v. Carpenter, at text accompanying note 27 supra, and The Practical Register in Chancery, at text accompanying note 34 supra; and compare the statement in Langston $v$. Boylston, 2 Ves. Jr. 101, 109, 30 Eng. Rep. 543, 547 (Ch. 1793), that "an interpleading bill is exactly upon the footing of an injunction to stay waste."

${ }^{60} 2$ Bro. C. C. 149, 29 Eng. Rep. 86 (Ch. 1787). See also Birch v. Corbin, 1 Cox 144, 29 Eng. Rep. 1101 (Ch. 1784), in which the defendant bankers, against whom coinpeting claims had been made, were directed to file a bill of interpleader if they wished to stay plaintiff's effort to assert his claim. This is one of the procedural alternatives that had been descrihed in The Practical Register in Chancery and in Bohun. See note 36 supra. See also Hodges v. Smith, 1 Cox 357, 29 Eng. Rep. 1202 (Ch. 1787).

61 In the sense that he was challenging the vahdity of claims of persons holding title 
Hardcastle $^{62}$ was a bill by a wharfinger-warehouseman having custody of a quantity of tallow whose ownership had come into dispute between the consignor of the tallow, the consignee and the vendees of the consignee. The only point discussed in the report again was that of costs; the interpleader itself was allowed without question or apparent hesitation, as plainly it should have been.

Langston $v$. Boylston ${ }^{63}$ decided in 1793 , presented the classic case of a bailee confronted with the conflicting claims of the bailor and those claiming in garmishment proceedings to be the bailor's creditors. ${ }^{64}$ No objection to plaintiff's obtaining interpleader was seen in the circumstance that he had received the goods as an agent acting for the bailor and under his instruction. Indeed, an unreported case was cited as a precedent for interpleader in such a situation. ${ }^{65}$ In later decisions, this circumstance was thought to be a reason for refusmg interpleader.

under his landlord. We do not wish to make much of this point; we only observe that the court made nothing of it.

A case of which there is no direct report appears to establish squarely that until 1790 there was no objection in principle to a tenant filing an interpleader naming his landlord as one of the defendants. In Smith v. Target, 2 Anst. 529, 530, 145 Eng. Rep. 957 (Ex. 1795), there is a note of the case of Surrey v. Lord Waltham, decided February 28, 1785: A man named Olmius devised estates among his children. Waltham, "representing himself to be entitled to grant leases thereof," demised to plaintiff and received the rents. Olmius' children thereupon claimed the rents from plaintiff and threatened "to distrain or sue for the same, or bring ejectunents." Plaintiff was granted interpleader, pursuant to which he paid the rents into court and, obtained an injunction against the threatened proceedings. See also note 73 infra for a further statement of the case.

622 Cox 278, 30 Eng. Rep. 129 (Ch. 1791). See also Edensor v. Roberts, 2 Cox 280, 30 Eng. Rep. 130 (Ch. 1791).

632 Ves. Jr. 101, 30 Eng. Rep. 543 (Ch. 1793).

64 The opinion covered a number of points of tangential interest. For one thing, the Chancellor asked whether there was "any case in which a bill of interpleader has been brought to a hearing," and concluded that there had been none. This is not so strange when it is called to mind that if the injunction staying other actions had been granted against the defendants (as it ordinarily would have been), then the defendants wonld have had no other course, aside from settlement, than to frame an issue between themselves for a trial at law before a jury. The implication of the question, therefore, is that once it was decided that a bill for interpleader was properly maintainable, the Court of Chancery, for practical purposes, was done with the case. This would pretty well make nonsense of the proposition subsequently advanced in Crawshay v. Thornton, 2 Myl. \& C. 1, 40 Eng. Rep. 541 (Cb. 1837), that the preservation of the claimant's right to jury trial was a reason for refusing interpleader.

It was also observed that plaintiff should have obtained relief by demanding that the bailor defend the garnishment suit and seeking a stay from the King's Bench of the trover action which the bailor had brought in that court. But it was held that the availability of such a remedy was no bar to equitable interpleader. The traditional "adequacy test" of equitable jurisdiction had become to that extent a dead letter.

B5 Field v. Todd, stated in 2 Ves. Jr. at 104, 30 Eng. Rep. at 545: Dewhurst \& Co., a New York firm, purchased goods from $S$ in London and had them dehivered to Field for packing and shipping. Todd and creditors of Dewhurst sued that finn and attached the 
Of these cases it might be said, so far so good. The turning point came in Dungey v. Angove, ${ }^{66}$ in 1794 . To this decision we may attribute the burgeoning technicality that before long choked up the interpleader remedy. ${ }^{67}$

\section{B. Dungey v. Angove: Pomeroy's First and Second Requirements}

Dungey v. Angove was one of those bad cases-redolent with fraud and inviting a swift and emphatic disposition-that makes hard law. Plaintiff Dungey had leased premises from defendant Angove. A certain Hernal, claiming that Angove held in trust for him, had brought an ejectment action against plaintiff, which however had been non-pros'd. Plaintiff nevertheless refused to pay rent to Angove, asserting doubt whether Angove was owner of the premises. He then filed suit for interpleader against Angove and Hernal. Hernal's answer to plaintiff's bill, setting up his alleged claim to be the beneficiary of the trust, was not on oath, itself a ground for suspicion. Moreover, it came out at hearing that Hernal had conveyed his interest, whatever it might have been, to Stephenton, who was the solicitor for plaintiff Dungey. It so snielled that the Chancellor ordered an inquiry, which resulted in a finding that the whole business was a sham and in an order striking the solicitor from the rolls. ${ }^{68}$

In a frame of mind apprehending these shenanigans, Chancellor Loughborough attacked the question whether under the rules of interpleader the plaintiff's bill should be considered a proper one. The report contains a rather full statement of the dialogue between him and counsel, ${ }^{69}$ and requires detailed examination.

The Chancellor: The bill "ought to be dismissed on the face of it; being an interpleading bill brought by a tenant under a lease agamst his landlord; because a stranger set up a title adverse to the landlord."

goods in Field's hands. $S$ thereupon demanded return of the goods from Field, claiming a right of stoppage in transitu for nonpayment of the price. Field interpleaded Todd and $S$.

862 Ves. Jr. 304, 30 Eng. Rep. 644 (Ch. 1794).

67 Those who share the authors' predeliction for historical intricacy will perhaps recall that it was only seven years earher that another fateful decision, Fell v. Brown, 2 Bro. C.C. 276, 29 Eng. Rep. 151 (Ch. 1787), threw the necessary parties rule into confusion. See Hazard, supra note 18, at 1274 .

68 See 2 Ves. Jr. at 313,30 Eng. Rep. at 649.

69 The burden of the argument was with Mitford, the harrister-not the impugned solicitor-for plaintiff. Mitford was already one of the most learned students of Chancery practice, as is attested hy the rapid and general respect that his treatise achieved.

702 Ves. Jr. at 304, 30 Eng. Rep. at 645. Loughborough cited no authority. If he had in mind Earl of Thanet v. Paterson, 3 Barn. 247, 27 Eng. Rep. 632 (1738), discussed at text 
Plaintiff: "The tenant would be hable to an action of trespass for his enjoyment."'t1

The Chancellor: "Then he will bring an action against his landlord upon the covenant [of quiet enjoyment] in his lease. I can conceive a tenant entitled to bring a bill, where two persons dispute, which is the representative of the lessor; but ... how monstrous ... if it was in the power of the tenant to make the landlord, at law the Defendant in the ejectment, disclose his title by an interpleading bill. The only case, in which a tenant can come into this Court upon such an interpleading bill is, where the lessor has done some act himself to embarrass the tenant, which is the case of a mortgage." 72

Plaintiff: "There is good authority for such a bill.",73

The Chancellor: "In all these cases, the party has a right to the specific money: but the case of a tenant who disavows his landlord, is different. He never can be called upon to pay the rent to the other person.... [The third party] may eject him; and may bring action for use and occupation: but he never can for the rent. It is a different demand. The parties interpleading inust each in supposition have a right to the same demand."74

Plaintiff: "It will in effect be the same action."

accompanying note 41 supra, it should be recalled that in Paterson the supposed conflicting claimants had not asserted their claim, see note 47 supra, while in Dungey v. Angove the "stranger" Hernal had actually brought ejectment. It is hard to toss this off as simply "setting up" an adverse title. Paterson, moreover, involved a copyhold tenant who could absolve himself of liability by paying the person in possession. See note 44 supra and accompanying text. A tenant under a lease could not do this.

71 That is, an action by the stranger.

722 Ves. Jr. at 304, 305, 30 Eng. Rep. at 645.

73 At this point Mitford made a long recitation of the precedents, referring to Field $v$. Todd, supra note 65, Surrey v. Lord Waltham, supra note 61, and Aldrich v. Thompson, sub nom. Aldridge v. Thompson, 2 Bro. C.C. 149, 29 Eng. Rep. 86 (Cl. 1787), supra note 60. He also referred to the unreported case of Wood $v$. Kaye, decided by Lord Thurlow a few years before: "There a bouse was devised to trustees for the separate use of Mrs. Kaye. . . The trustees not acting, Mr. \& Mrs. Kaye entered [and thereafter] executed a lease to Wood. ... [Later] the trustees ... msisted ... they had a right to receive the rent. ... [T]he tenant filed a bill. It was insisted, as it is now, that a person, who has taken a lease from another, could not file such a bill. The Chancellor said ... that if the landlord ... does not take care of the defence, the consequence is, the tenant has a right to come into equity." 2 Ves. Jr. at 305-06, 30 Eng. Rep. at 645. Wood v. Kaye seems on all fours with Dungey v. Angove. And Mitford's description of Surrey v. Lord Waltham, which there is no reason not to credit, indicates it too was directly in point: "In Surrey v. Lord Waltham ... under the will of Mr. Olmius, Lord Waltham conceived himself to be absolutely entitled to an estate. ... He had let two farms to Surrey. A person claimed under the will ... and threatened ejectment. Lord Waltham calling for his rent, the tenant filed a bill of inter"pleader." 2 Ves. Jr. at 306, 30 Eng. Rep. at 645. See also note 61 supra.

742 Ves. Jr. at 307, 30 Eng. Rep. at 646. 
The Chancellor: "Where there is a demise, an action for use and occupation cannot be brought by the lessor: but it must be upon the deed for the rent. If another person claims, he may bring an action for use and occupation. The case of Wood v. Kaye ${ }^{75}$ is ... directly opposite to this. The title of the trustees were derivative from that of the cestui que trust; and was consistent with it. The tenant did not come to disavow the title of the landlord. 276

Defendant Angove: "In Metcalf v. Hervey ... Lord Hardwicke expressly lays it down, that such a bill cannot be as to the possession; but must be as to the payment of some demand in money. That is a direct authority, that there cannot be a bill of interpleader to stop an ejectment."

Plaintiff: "The attempt to confine interpleader to cases of mere bailment is absurd; for in that case it may be compelled at law."

The Chancellor: "I had imagined, that nothing was better known ... than that there was no possibility of filing a bill of interpleader against an ejectment.... The reason is manifest: for upon the definition of it a bill of interpleader is, where two persons claim of a third the same debt or the same duty.... In the case of another person claiming against the title of [the tenant's] landlord it is clear, unless he derives under the title of the landlord he cannot claim the same debt. The rent due upon the demise is a different demand from that, which some other person may have upon the occupation of the premises."?77

The bill was thereupon dismissed.

To summarize the points traversed, interpleader should not be permitted because:

1. A tenant cannot interplead against his landlord, unless the landlord himself has done "some act himself to einbarrass the tenant."

2. It would be monstrous if the landlord, compelled to defend an ejectment action brought against his tenant, could be forced by the tenant to disclose his title in an interpleader suit.

3. The claims confrontimg the tenant do not relate to the "saine debt or duty." The landlord's claim is for rent upon the lease; the stranger's claim is for ejectment or for damages for use

75 See note 73 supra.

762 Ves. Jr. at 307, 30 Eng. Rep. at 646.

772 Ves. Jr. at 310, 30 Eng. Rep. at 647. 
and occupancy. In Wood v. Kaye the third party's claim was "derivative ... and so consistent with" the landlord's claim.

Comparison of these points with the quotation from Pomeroy at the beginning of this monograph shows that the opinion in Dungey v. Angove contains the conceptual imgredients of the first two supposed requirements for interpleader: (1) that the "same debt or duty" be claimed, and (2) that the titles or claims be "derivative" from each other. This is an appropriate place to challenge the reasoning of Chancellor Loughborough, the interpretation of Dungey v. Angove by Pomeroy, and therefore the soundness of the first two putative requirements for interpleader.

\section{The Reasoning in Dungey}

As to Loughborough's proposition that a tenant cannot interplead his landlord except where the landlord himself has done some act after the lease to impugne his title: No such rule had ever been advanced. Some precedents, as we have seen, allowed a tenant interpleader without qualification. ${ }^{78}$ Hardwicke, in Earl of Thanet v. Paterson, had indicated that he might without qualification deny a tenant interpleader against his lord in order to fortify the landlords' position vis-à-vis tenants in general. This is a point of view that is intelligible, even if one-sided. Nevertheless, Loughborough was prepared to allow a tenant interpleader against his landlord to meet some kinds of threats to his tenancy and yet not to meet others: Interpleader lies if the embarrassment came from events after the lease, but not before it. It is impossible to see any organizing principle on which he based this line of demarcation, except to leave the corpses of precedent where they lay. Why should it make the slightest difference whether the source of the tenant's embarrassment was some act of the landlord after making the lease rather than-as in sucl cases as Surrey v. Lord Waltham ${ }^{79}$ - the landlord's being without title to demise in the first place? Are we to lave it that a tenant is to be protected against the blunderer who liad title but messed it up, but not against the interloper who never had title in the first place? This is estoppel with vengeance and surely makes no sense under theories of tenancy, modern or medieval. Yet, it became a link in the cham of interpleader doctrine that comes down to this very day. ${ }^{80}$

Loughborougli's second proposition, that it would be "monstrous" if the landlord could be compelled to disclose his title in an interpleader

78 See especially cases cited in note 73 supra.

79 See note 61 supra.

80 The notion that a tenant cannot question his landloard's title in interpleader did not pass directly into Pomeroy's four-fold requirements. Rather, as we shall see, its theory of estoppel was adopted and applied in bailment cases and via these cases, notably Crawshay $v$. Thornton, was brought into Pomeroy's system. 
suit, invites two answers, a short and a long. The short answer is that there was no general rule immunizing a landlord from discovery of his title in an equity suit, so long as there was good ground for the suit itself. And in Metcalf v. Hervey, the only previous interpleader case expressing concern about opening the landlord's title to disclosure, Hardwicke, though refusing the interpleader, had permitted the discovery. ${ }^{81}$

The other answer to Loughborough requires a look at the eighteenth century law of landlord and tenant. Prior to 1738, there appears to have been no rule of any kind that a tenant could not question his landlord's title in judicial proceedings; he could commit a wrong by repudiating his landlord's title out-of-court, but that of course is something quite different. Indeed, it was because the tenant prior to 1738 could question his landlord's title in all mauner of legal proceedings that Parliament enacted the Landlord and Tenant Act of $1738,{ }^{82}$ the source of Loughborough's notion that the tenant could not interplead his landlord. That act undertook to cut a wide if ragged swath through the law of landlord and tenant. In general, it attempted to facilitate the landlord's collection of rent by revising various aspects of common law actions between landlord and tenant. ${ }^{83}$ It certainly did not flatly or generally pre-

811 Ves. 248, 249, 27 Eng. Rep. 1011, 1012 (Ch. 1749): "Then even supposing the interpleading part of the bill, which, I am not willing to allow, to be out of the case, and considering it as a bill for the discovery of the defendant's title to possession of the estate, and to the rents and profits ... the plaintiffs are intitled to that discovery: and the defendants having demurred to the whole bill for discovery as well as rehef, it ought to be over-ruled."

8211 Geo. 2, c. 19 (1738).

83 What the act provided in relevant part was this: (1) It streamhined and made more rigorous and more widely available the landlord's remedy of distress, the procedure for seizing the tenant's chattels for nonpayment of rent. These provisions were contained in the first ten paragraphs of the act.

(2) In its eleventh paragraph, the act attacked an aspect of the problem of preserving the landlord's possession against the intrigues of his tenant. This paragraph first recited that "the possession of estates in land ... is rendered very precarious by the frequent and fraudulent practice of tenants, in attorning to strangers [i.e., formally recognizing a stranger as landlord], who claim title to the estates of their respective landlord or landlords ... who by that means are turned out of possession of their respective estates, and put to the difficulty and expence of recovering the possession thereof by actions or suits at law. ..." It then provided that an attornment by a tenant sbould be void and "the possession of their respective ... landlords . . shall not be deemed ... affected by any such attornment," certain situations excepted. The purpose of this provision was to disable the tenant from disrupting the continuity of his landlord's vicarious possession by the device of repudiating his original tenancy and acknowledging a stranger as lord of the land in question. It did not, strictly speaking, prohibit the tenant from questioning his landlord's title; it closed off a way by which he could subvert it.

(3) The act next attempted to protect the landlord against collusive ejectment actions. It recited that "great inconveniences have frequently happened to landlords by their tenants secreting declarations in ejectment, which have been delivered to them, or refusing to appear to such ejectments, or to suffer their landlords to take upon them the defence thereof." To 
clude the tenant from challenging his landlord's title under all circumstances. The question remained as to what it did do in this regard.

The answer was not made clear prior to Loughborough's utterances in Dungey v. Angove. The fullest statement of the statute's consequences is in the argument and decision in Syllivan v. Stradling, a Common Pleas case in $1764 .^{84}$ This was an action of replevin of two heifers. The avowry (i.e., the answer) of the defendant landlord was the allegation that the animals were taken by distraint on land which the defendant had demised to one James Harris at a certain rent. To this avowry plaintiff pleaded that defendant had no estate in the premises in question, and therefore could not properly have distramed. Defendant contended that plaintiff could not properly interject the "collateral issue" of ownership of the premises. The issue thus was whether defendant's title could be drawn in question in an action for replevin of distrained chattels. The point was apparently a difficult one, for the case was twice argued and is reported at length. ${ }^{85}$

provide some assurance that the landlord would not be ousted from legal possession by such a failure of his tenant to notify him of ejectment proceedings (in which the tenant is formally the defendant), it was laid down in paragraph 12 of the act that the tenant must give the landlord notice of any declaration in ejectment, on pain of forfeiting three years' rent. Paragraph 13 provided that the landlord might appear in an ejectment action as a defendant or, where the tenant had defaulted, obtain a stay of execution.

(4) The landlord was given a new right of action against a tenant holding otherwise than under a demise by deed, i.e., holding by customary, oral or other informal tenancy. In such instances, the landlord was permitted to sue in an action on the case. He was also permitted to introduce in evidence "any parol demise or any agreement" even though the action was predicated on a quantum meruit principle. In substance, this was to make available to the landlord the simplified pleading and procedure of the common count in an action against a tenant holding by informal demise. Cf. AxIEs, LeCTURES ON LEGAL HISTORY 167-71 (1913).

(5) Paragraph 22 of the act undertook to simplify the landlord's procedural problems in actions of replevin. Replevin was the remedy of a tenant who as plaintiff sought to recover chattels taken in distraint by a landlord where the tenant claimed that no rent was due or that defendant had no title to the premises. Prior to the 1738 act a landlord defending a replevin would therefore have to be prepared to establish his title. Paragraph 22 provided that in defending a replevin action "it shall ... be lawful to and for all defendants in replevin to avow or make conuzance generally, that the plaintiff in replevin, or other tenant of the lands and tenements whereon such distress was made, enjoyed the same under a grant or demise at .... a certain rent ... or that the place where the distress was taken was parcel of such certain tenements ... without further setting forth the grant, tenure, demise or title of such landlord. ..."

842 Wils. K.B. 208, 95 Eng. Rep. 769 (1764).

85 Defendant made two arguments. The first argument was that the plaintiff should not, by pleading an absence of title in the defendant, throw upon the defendant the burden of establishing the strength of his title by replication. If plaintiff were permitted to do this, "it [would occasion] ... a greater prolixity in pleadings in replevin than there was before, for at common law the landlord ... was obliged to set out his title in his avowry or conusance at first." Moreover, this would put the landlord right back in the position from which the statute of 1738 had rescued him, namely having to be ready to establish his title in order to 
The plaintiff's most pressing argument relates directly to the problem of interpleader. Plaintiff argued that the tenant must be allowed to question the landlord's title because:

[I]f the lessor has nothing, the tenant is not safe in paying him the rent, because he may be sued for it again by the right owner of the land, and ... the statute [of 1738] could never intend to take away the right to controvert the lessor's title and subject the [lessee] to the danger of being hable to pay his rent twice. . . ${ }^{86}$

The court's response was a wavering one. They agreed that the issue of defendant's title was not raised by the pleadings before them. But this seems to have been because they regarded plaintiff as having the burden of setting forth the alleged defects in defendant's title, rather than casting on the landlord the burden of establishing title in himself, for, as the court said, "after a tenant has enjoyed the land ... he shall not be permitted to pry into the title, and pick holes in settlements and wills. . . ." One of the judges suggested a broader ground: "Perhaps there may be one case in a thousand where a tenant may have taken a farm upon a bad title; but in answer to that, he may recover his rent back again and damages. . . ."87

The only things that Syllivan $v$. Stradling made clear were that a tenant questioning his landlord's title would have to plead with particularity, and that he might not be able to challenge his landlord's title in those comnion law actions, such as replevin, which the Landlord and Tenant Act of 1738 had attempted to streamline. ${ }^{88}$ It raised the possibility that so far as common law remedies were concerned the tenant might be in jeopardy of paying twice for the use of the land. Surely this

collect his rent. Defendant's second argument was that the tenant should be estopped from denying his landlord's title in an action arising out of collection of rent, because having enjoyed the use of the land he should not resist paying for it.

Plaintiff countered by asking "whether the [statute] was intended to take away the lessee's right at common law to controvert the lessor's title and authority to make the demise in cases where the lease is not by deed indented? I conceive that it was not; it has given the lessor a new avowry, but has not taken away the lessee's right . . . to put the lessor to shew that he had such an estate, whereof he could make the demise. . . ."

802 Wils. K.B. at 214,95 Eng. Rep. at 772-73.

872 Wils. K.B. at 218,95 Eng. Rep. at 775.

88 Later on it was determined that the tenant under an informal demise could dispute his landlord's title by pleading with particularity that title was in another. See Rogers v. Pitcher, 6 Taun. 202, 128 Eng. Rep. 1012 (1815). And in a review of the law in 1822, it was said in Gravenor v. Woodhouse, 1 Bing. 38, 130 Eng. Rep. 16 (1822): "Of the general rule of law, that a tenant shall not be allowed to question the title of his landlord where he has originally received possession from him and has paid him rent, there is no doubt, ever since the case of Syllivan v. Stradling. ... [B]ut to the generahty of this rule there are exceptions. ... The supposed generality of the rule has been departed from in many cases. . ." Id. at 42,130 Eng. Rep. at 18. 
result does not support the conclusion that a tenant could not come into a court of equity to interplead his supposed landlord. On the contrary the constriction of the tenant's common law remedies accomplished by the Act of 1738 militates strongly for the equitable remedy. ${ }^{89}$

This brings us at last to Lougliborough's third proposition in Dungey v. Angove. This was that interpleader should be denied a tenant who has been sued by a third party, because the claim agamst the tenant by the third party does not relate to the "same debt or duty" as that owed the landlord: The third party's claim is for ejectment or for trespass or for an action on the case for use and occupancy; the landlord's claim is on the lease or oral demise. Lougliborougl qualified this proposition by acknowledging that in Wood v. Kaye $e^{90}$ a tenant liad been allowed to interplead his landlord and a third party, but distinguislied that case on the ground that there the third party's claim was "derivative" from the landlord's. The main proposition and the qualification, as we liave seen, found their way into Pomeroy's classic formula.

\section{Pomeroy's Interpretation of Loughborough}

It will be convenient to consider first the busmess about the "derivative" title. It las never been clear, either in the decided cases or as a matter of analysis, what is meant by a "derivative" title. Unless the third party claims by slieer naked force, which of course he never does in a court of law, his pretensions to title are founded on some antecedent ownerslip or ownerslip-creating event. Indeed, "title" is a short summary of the point that in some recognized fashion the given piece of land or personalty was marked off as the special preserve of a particular person. The concept of "title" is unintelhibible without reference to some such antecedent. Hence, any claim to title is in some sense "derivative." Thus, it is virtually a contradiction to say that interpleader will be refused in general but will be granted where the conflicting claims to title are "derivative."

89 If the tenant had actually been sued in ejectment, then the tenant would have a remedy at law for resolving his dilemma, for he could call on the landlord to defend the ejectment suit and thus fight out the question of title with the third party, the plaintiff in ejectment. See note 83 supra. But if the tenant were merely threatened with suit by the third party, or if the third party brought a suit for trespass or for use and occupancy rather than ejectment, the tenant would have no way to protect himself except by later suing his landlord for indemnity under the landlord's covenant of quiet enjoyment. Hence, the tenant's remedy of vouching in the landlord as defendant in an ejectment action was of limited and contingent availability.

${ }^{90}$ See note 73 supra.

01 Pomeroy's reformulation specifies that the claims emanate from "a common source." What ohstacle is there in his system to thinking of Adam's rib as the common source of all claims? 
If it is insisted that Loughborough should be understood as saying that the one claim must be derivative from the other claim, two responses present themselves. In the first place, why, for Heaven's salke? What possible relevance has this fact to any aspect of the tenant's problem with his landlord and the third party intruder? In the second place, in Wood v. Kaye the title of the third party claimant (the trustees to whom the land had been devised) did not hold title derivative from the person who had made the lease (the trust beneficiaries who had leased the land to plaintiff when the trustees had failed to act). There was neither conveyance nor succession of title between them. The beneficiaries claimed title against the trustees because they had failed to exercise their duties as such. One could as well say that an adverse claimant's title is derivative from that of the person dispossessed because the latter had claim to title but lost it through neglect.

In the last analysis it seems quite plain that Loughborough's suggestion about "derivative" title was an argumentative contrivance to sidle around a precedent standing squarely in his way.

Even at this, Loughborough had it that Wood v. Kaye was an exception to the general rule that in interpleader the claims must relate to "the same debt or duty." That is, he said, even if the claims supposedly did not relate to "the same debt or duty," they could nevertheless be interpleaded if as in Wood v. Kaye they were "derivative." "The same debt or duty" and "derivative" claims were therefore alternative conceptual vehicles for allowing interpleader. The astonishing historical fact is that in Pomeroy they were stated as cumulative requirements, so that in his conception it was necessary both that the claims relate to "the same debt or duty" and that one be "derivative" from the other..$^{22}$ What started in Loughborough's hands as a crude effort to distinguish a prior case emerged in Pomeroy's as a discrete abstraction. This appears to be the origin of the second of the supposed requirements for interpleader.

There remains for consideration Loughborough's main thesis that the interpleaded claims must relate to "the same debt or duty." It will be recalled that it was Mitford's treatise in 1789 in which equitable

02 It is possible to read Wood v. Kaye differently. Loughborough may be taken to mean that the claimants were both seeking the rent itself and therefore were seeking the "same debt." If such a reading is correct, it becomes difficult to see why it was relevant to decide whether the claims were "derivative," for under Loughborough's definition of interpleader it seemed enough that the claims related to the "same debt or duty." On this analysis, it was Loughborough who invented the new and redundant requirement for interplender, and Pomeroy is guilty of no worse crime than uncritical reiteration of old dicta.

In any case, the transmission of thought was not directly from Dungey $v$. Angove in 1794 to Pomeroy's treatise in 1883. We have foreshortened the historical perspective in the interests of brevity and clarity. 
interpleader was for the first time defined in this way. ${ }^{93}$ Theretofore, interpleader had been described as a proceeding by a person in a quandary as "to whom he ought of right to render a debt or duty." has already been observed how the image of interpleader thus transmuted, almost imperceptibly, from the hife portrait of a three-cornered squabble to the geometry of superimposed legal abstractions. Abstraction is of course essential to the legal process, but it has to be done with care, for otherwise false puzzles result. To define interpleader-to state its abstract form-as the resolution of claims to "the same debt or duty" is careless and wrong, as we shall now undertake to show. Dungey $v$. Angove is as good a case as any to indicate why.

The point of departure is to recognize that a legal claim, still less a "debt" or a "duty," does not exist in materiahty. It is an intellectual construct used to express relationships between persons. It is a construct that can be built to a wide range of specification, depending on the purpose for which it is to be used.95 The same two people can be referred to as (1) persons claiming interests in Blackacre, (2) persons claiming title to Blackacre, (3) persons claiming a right to a legal remedy vis-à-vis the tenant of Blackacre, (4) persons claiming respectively vis-à-vis the tenant a right to the rents from Blackacre and the right to repossess it. Any other relational statement can be similarly expanded or reduced in specification.

If the terms used in building the construct are broad enough, the persons whose relationship is referred to can always be placed in the same category. Thus, if the enumeration above were applied to Dungey $v$. Angove, the claimants Angove and Hernal could be described as having "the same claim" in constructs (1), (2), and (3), but not in (4). Conversely, if the terms used in building the construct are narrow enough, the persons can always be placed in different categories. This would be true in construct (4) above, and a fortiori in any construct built of more specific terms. Hence, it is not only possible but simple to push persons claiming against the middleman in and out of the category of "persons claiming the same debt or duty," by manipulating the specifications in which the claim, the debt or the duty, is constructed.

Because it is possible to put the conflicting claimants in the identical category or not depending on the way the categories are constructed, it

${ }^{03}$ See text accompanying note 58 supra. It is one of the small ironies of procedural history that Mitford as counsel for plaintiff in Dungey v. Angove was the first to be hoist by this doctrinal petard.

04 See text accompanying note 34 supra.

95 Cf. Michael \& Adler, The Trial of an Issue of Fact, 34 Corosr. L. Rev. 1224, 1462 (1934); Cook, "Facts" and "Statements of Fact," 4 U. CEI. L. REv. 233 (1937). 
does no good to ask "Do the claimants assert the same claim?". For this is to ask "Are the persons in the same category?", to which the answer of course is, "It depends on what category you have in mind." Accordingly, to inquire whether interpleader should be allowed by asking whether the claimants claim the same debt is to ask a pointless question, unless a particular category has been assumed in the question. That, of course, is to assume the answer to the crucial question, which is: "Should the claims of these defendants in interpleader be regarded as being one, single 'same' category, it being imderstood that if they are interpleader will be allowed, and if they are not it will be disallowed?" In short, unless the specifications of the category are explained the question whether interpleader should be allowed is begged.

The question, "Do the parties claim the same debt or duty?", for the purposes of determining whether interpleader should be allowed is one that can only be begged. Mitford invited its being begged by asking it in the first place; Loughborough begged it in Dungey v. Angove; Pomeroy put it down in the book, and we have been solemnly begging it ever since. It was the place of Loughborough in Dungey v. Angove to confer on the question its original authority. And therefore, it is from that case that we inherit not only the second but also the first of the "classic requirements" for interpleader.

\section{Confusion Confounded}

The pronouncenients in Dungey v. Angove flowed on as precedent in different directions at uneven rates. In cases involving landlord and tenant their impact was rapid and close to paralyzing. In the following year it was held, as though so long established that any fool would know it, that "It is against the general policy of the law, that a tenant should in any shape be allowed to call in question the title of his landlord, and accordingly he caumot compel him to interplead." ${ }^{.16}$ But then, no doubt because this rule was too inuch even for the late Georgians, there was a little backing and filling. In Cowtan v. Williams in 1803, it was held that

${ }^{26}$ Smith v. Target, 2 Anst. 529, 145 Eng. Rep. 957 (1795). The argument of plaintiff's counsel was a careful exposure of the question begging in Dungey v. Angove, a case which he sought to distinguish on the ground that it was "decided principally on the ground of very gross fraud and collusion." 2 Anst. at 531, 145 Eng. Rep. at 957. Accord, Jobnson v. Atkinson, 3 Anst. 798, 145 Eng. Rep. 1043 (Ex. 1795), where the "same debt" requirement was applied with yet stricter rigor ("these parties claim different things, the one the rent reserved, the other the unliquidated value of the occupation; an interpleader only lies where the same certain sum or thing is demanded by the claimants" [Emphasis added.]); Woolaston v. Wright, 3 Anst. 801, 145 Eng. Rep. 1044 (Ex. 1795).

Even in retrospect it is amazing how the somewhat uncertain refusal to allow interpleader to the tenant in Dungey v. Angove was so quickly transformed into an inflexible prohibition. 
a tenant could interplead his landlord if the cause of his difficulty was some act of the landlord subsequent to the lease, ${ }^{97}$ a qualification that was recognized in other cases. ${ }^{98}$ But in 1823 a dictum in an interpleader decision on the equity side of Exchequer seemed to foreclose the tenant any remedy at all..$^{9}$ In this confused state, which cannot be synthesized into any principle that is sensible to the purpose of the interpleader remedy, the law of interpleader of landlord by tenant came to rest.

\section{Pomeroy's Third and Fourth Requirements}

The cases after 1800 mostly arose out of commercial transactions, reflecting the fact that England was becoming not a country of squires but a nation of shopkeepers. It is in the commercial cases that there emerged what were to become the third and fourth of Pomeroy's requirements for interpleader: The stakeholder must claim no interest in the fund and he must have incurred no "independent hability" to any of the claimants. The pedigree of these requirements is scarcely better than that of those already examined.

We may pass the first two decades of the nineteenth century quickly. ${ }^{100}$ In a number of cases interpleader was granted without sig-

979 Ves. Jr. 107, 32 Eng. Rep. 542 (Ch. 1803). This was a variation of a qualification Loughborough had indicated in Dungey v. Angove, where he conceded that an interpleader might be allowed "where the lessor has done some act himself to embarrass the tenant." 2 Ves. Jr. at 305, 30 Eng. Rep. at 645. See text accompanying note 72 supra. Loughborough did not say, though he quite possibly meant to imply, that the landlord's embarrassing act had to occur after the making of the lease. Lord Eldon, who decided Cowtan v. Williams, was explicit that the tenant could interplead when the source of the difficulty was an act of the landlord subsequent to the lease. He did so in acknowledgment of the decision in Aldridge v. Thompson, 2 Bro. C.C. 149, 29 Eng. Rep. 86 (Ch. 1787), discussed at text accompanying note 60 supra which he referred to as "Lord Thomond's Case." Lord Thomond appears to be the Earl of Inchiquin mentioned in the report of Aldridge v. Thompson. See 14 Dicr. Nat. Bio. 760.

98 Clarke v. Byne, 13 Ves. Jr. 383, 33 Eng. Rep. 338 (Ch. 1807); Angell v. Hadden, 15 Ves. Jr. 244, 33 Eng. Rep. 747 (Ch. 1808). See also Jew v. Wood, Cr. \& Ph. 185, 41 Eng. Rep. 461 (Ch. 1841), which appears to be the only other reported English case of interpleader between tenant and landlord in the first half of the nineteenth century.

90 Stephens v. Callanan, 12 Pri. 158, 161, 147 Eng. Rep. 685-86 (Ex. 1823): "Since the statute of the 11th of George the $2 \mathrm{~d}$, called the statute of Landlord and Tenant, Courts of Equity have so exercised the salutory jurisdiction which they possess, as to exclude all contest by tenants of their landlords' title, by analogy with the provisions of that act first adopted by Lord Rosslyn [Lord Loughborough] in the case of Dungey v. Angove. The tenant must stand or fall by the strength or weakness of his landlord's title. . .."

100 It is interesting to observe that the rate of flow of reported decisions began to step up at an extraordinary rate after the turn of the eighteenth century, an increase that appears of equal or greater rate if of much less absolute magnitude than the "law explosion" of the mid-twentieth century. If one reads a body of cases from this period in clronological order, as we have bad to for this study, one gets the impression that the judges and lawyers suddenly felt themselves in a sea of law with only rudimentary navigational techniques. In particular, they seem to bave had almost no compreliension of the implications of general language and hence the potential difficulties encountered in using it. 
nificant obstacle. ${ }^{101}$ In others it was denied on grounds of substantive policy of hittle current interest, and of no relevance in the development of interpleader. ${ }^{102}$ There were also denials of interpleader on fairly straightforward procedural grounds that make sense to this day. ${ }^{103}$ And in one case, it was held simply and, so far as appears, plausibly that

101 Aldridge v. Mesner, 6 Ves. Jr. 418, 31 Eng. Rep. 1122 (Ch. 1801) (interpleader by an auctioneer confronted by buyer's demand that sale be rescinded and by seller's demand for sale proceeds); Lowndes v. Cornford, 18 Ves. Jr. 299, 34 Eng. Rep. 330 (Ch. 1811) (plaintiff debtor confronted with conflicting demands from bankruptcy commissioners allegedly appointed for his creditor and from creditor himself); East India Co. v. Edwards, 18 Ves. Jr. 376, 34 Eng. Rep. 359 (Cl. 1811) (debtor confronted with dispute over validity of a purported assignment of the debt); Stevenson v. Anderson, 2 Ves. \& B. 407, 35 Eng. Rep. 373 (Cl. 1814) (plaintiff, a banker, was given bills of exchange to loold to secure payment in a sale of goods, then confronted with seller's demand to enforce the contract and the buyer's to rescind it); Morgan v. Marsack, 2 Mer. 107, 35 Eng. Rep. 881 (Cl. 1816) (insurer confronted with conflicting claims to policy proceeds; interpleader allowed even though dispute related to only part of the proceeds). See also East India Co. v. Bazett, Jac. 91, 37 Eng. Rep. 784 (Ch. 1821); Wright v. Ward, 4 Russ. 215, 38 Eng. Rep. 786 (Ch. 1827).

102 Slingsby v. Boulton, 1 Ve. \& B. 334, 35 Eng. Rep. 130 (Ch. 1813) (slicriff who had made an allegedly excessive levy may not interplead the judgment debtor and judgment creditor; a sheriff is to be held strictly liable-presumably as a deterrent against officious intermeddling); Harlow v. Crowley, 1 Buck. 273 (Ex. 1818) (interpleader refused as between debtor and his commissioners in bankruptcy because the validity of the commission may not be challenged collaterally).

In Slingsby v. Boulton, supra, there are some obiter dicta that may have influenced later doctrine. Chancellor Eldon in this case said that "the plaintiff always admits a title against himself in all the defendants. A person cannot file a bill of interpleader, who is obhiged to put his case upon this, that as to some of the defendants he is a wrongdoer." The first sentence is suggestive of the proposition that the interpleading plaintiff must be perfectly neutral, an idea that appeared in definite form a few years later. The second sentence was simply false, unless "wrongdoer" was intended only to mean "fraud-doer," in which case it is but an application of the familiar "clean bands" rule. Cf. Hackett v. Webb, R. t. F. 257, 23 Eng. Rep. 141 (Ch. 1676), discussed at text accompanying note 23 supra.

103 Burnett v. Anderson, 1 Mer. 405, 35 Eng. Rep. 723 (Ch. 1816): The plaintiff was a wharfinger to whom goods had been delivered by $B$, who had obtained them from $A$, who bad in turn obtained them from $S$. $A$ went broke before be paid $S$, and $S$ claimed a seller's lien on the goods; $B$ contended the sale had been completed to $A$ and that $B$ therefore succeeded to title. In the face of these claims plaintiff delivered the goods to $S$ under an indemnity agreement and then sought interpleader to resolve the question of title between $B$ and $S$. It seems clear enough that plaintiff should not have been allowed to interplead, first on account of laches and estoppel en pais in delivering the goods to $S$ with knowledge of $B$ 's claim, and, second, because his taking the indemnity agreement from $S$ was a voluntary acceptance of a remedy that was adequate if $S$ was solvent, a question plaintiff could be leeld to have determined for himself. The court's opinion seems to amount to this: "Plaintiff, having parted with the goods, stood no longer in a situation entitling him to put the claimants to an interpleader. It was not enough to say that, in the result of such a proceeding, the party entitled might have the value of his property; he was entitled to it specifically."

It was one of those strange oecasions in which conceptual considerations completely overbore practical expediency in Lord Eldon's mind, for he mentioned but attaclied no sigmificance to the fact that the goods in question were perishable. In accord with Burnett v. Anderson is Barclay v. Curtis, 9 Pri. 661, 147 Eng. Rep. 215 (Ex. 1821). 
plaintiff needed no interpleader because he stood in no jeopardy from one of the claimants. ${ }^{104}$

At this point in our account it will be helpful to consider separately the channels of cases from which there flowed the third and fourth of Pomeroy's requirements for interpleader. There are some cross-currents between the two, but rigid fidelity to chronology can here be safely sacrificed to clarity of exposition.

\section{1. "Independent Liability"}

We turn first to the development of the fourth requirement, that there can be no interpleader if the plaintiff has an "independent liability" to one of the claimants. The first step was taken in Nickolson v. Knowles decided by Vice Chancellor Leacl in $1820 .^{105}$ Plaintiff had been employed by $B$ to procure insurance on a ship, which he did. The ship thereafter sank and $B$ went bankrupt. $B$ 's assignees in bankruptcy then directed plaintiff to obtain and remit to them the proceeds of the insurance, which plaintiff undertook to do. At this point $C$ appeared and claimed to have been $B$ 's partner in the shipping venture and therefore entitled to part of the insurance proceeds. Plaintiff sought to interplead $C$ and the assignees in bankruptcy. Interpleader was denied on the ground that plaintiff, as agent for the assignees, had no other duty than to remit the proceeds to them, regardless of $C$ 's claims. "A mere agent to receive for the use of another could not, by notice, be converted into an implied trustee. His possession is the possession of his principal."

The result of the case seems erroneous and the reasoning is certainly so. The decision would make sense only if the plaintiff could have exonerated himself by paying the funds to his principal, which Leach did not suggest was the law, and which in fact seems not to have been the law. Plaintiff probably would have been liable to $C$ if he liad parted with the funds. ${ }^{100}$ However that may be, it had long been established that the

104 Lowe v. Richardson, 3 Madd. 277, 56 Eng. Rep. 511 (V.C.C. 1818) (bailee of goods covered by a bill of lading, confronted with seller's claim of fraud with respect to quality of the goods, is exonerated simply by delivering the goods to the holder of the bill).

In an editorial note appearing at $3 \mathrm{Madd} .564$ it is said that "in ... Morley v. Thompson, 29 July $1819, \ldots$. Vice Chancellor [Leach retracted Lowe.]" This reversal seems to be of no significance to our main theme.

1055 Madd. 47,56 Eng. Rep. 812 (V.C.C. 1820).

100 Stephens v. Elwall, 4 M.\&S. 259, 105 Eng. Rep. 830 (Ch. 1815), decided that an innocent agent could be held liable as a converter of goods in his possession if it turned out that his principal lacked title. On the other hand, there is a dictum in a case on the law side of Exchequer, Roberts v. Ogilby, 9 Pri. 269, 147 Eng. Rep. 89 (Ex. 1821), decided shortly after Nickolson $v$. Knowles, note 105 supra, that suggests that the agent would be exonerated by payment to his principal. Roberts $v$. Ogilby cites no authority in support of this suggestion, however, and does not mention Stephens v. Elwall, supra. It is moreover distinguishable. In any event, as noted in the text, the important fact was not whether on 
risk of double vexation, not the certitude of double liability, was sufficient to justify interpleading the disputants; ${ }^{107}$ the claims against plaintiff were clearly of enough substance to cause a reasonable man to worry. As to the proposition that an agent could not interplead his principal, a line of cases ante-dating Nickolson by a century and a half sustained the right of an agent to interplead in such a circumstance. ${ }^{108}$

In view of the formidable considerations of precedent and practical policy that stooc before Leach in Nickolson v. Knowles, it is impossible to understand what seized him on that occasion unless it was a suspicion of fraud similar to that which provoked Loughborough in Dungey $v$. Angove, ${ }^{109}$ or a sudden zeal to purify the relation of agent and principal after the fashion of tenant and landlord. At any rate, Nickolson $v$. Knowles denied the agent interpleader.

The next step was taken in 1829 in Cooper v. De Tastet, also decided by Leach. ${ }^{110}$ Plaintiff was a warehouseman to whom a quantity of wool was delivered in the name of $B$. Thereafter, an order from $B$ directed plaintiff to transfer the wool to the name of $C$, which plaintiff did. Plaintiff next received a letter from $B$ and $D$ to the effect that actually $C$ liad no proper interest in the wool, that the wool should be put in $D$ 's name and that $D$ would indemnify plaintiff against any claims $C$ might thereafter make. Plaintiff transferred the wool to $D$ 's name. $C$ did make a claim, while $D$ continued to insist that the wool was properly his. Confronted by conflicting claims to goods in his custody, the plaintiff sought interpleader.

Leach dismissed the bill. He could have done so on the simple and impregnable ground that plaintiff, having satisfled himself by accepting $D$ 's promise of indemnity, was estopped to seek a refuge in interpleader. ${ }^{111}$ But what he did instead, unfortunately if unsurprisingly, was

due reflection a court should come to the conclusion that the agent would be exonerated but whether things looked dangerous to the agent when he had to decide what to do with the money.

107 See Corderoy v. Carpenter, R. t. F. 235, 23 Eng. Rep. 129 (Ch. 1675); text accompanying note 26 supra; 1 Eq. Cas. Abr. 80, 21 Eng. Rep. 893; BoHun, Cursus CanceiIARIAE 458 (2d ed. 1723), quoted in note 36 supra; Practical Register In Cinawcery 78 (Wyatt ed. 1800).

108 See Hackett v. Webb, R. t. F. 257, 23 Eng. Rep. 141 (Ch. 1676), text accompanying note 23 supra; Dowson v. Hardcastle, 2 Cox. 278, 30 Eng. Rep. 129 (Ch. 1791), text accompanying note 62 supra; Burnett v. Anderson, 1 Mer. 405, 35 Eng. Rep. 723 (Ch. 1816), note 103 supra. In Stevenson v. Anderson, 2 Ve. \& B. 407, 35 Eng. Rep. 373 (Ch. 1814), note 101 supra, which is on all fours, Chancellor Eldon had expressly observed that the agent properly interpleaded on account of his jeopardy of being "answerable to his Principals."

109 See text accompanying note 66 supra.

110 Tam. 177, 48 Eng. Rep. 71 (Ch. 1829).

111 See Burnett v. Anderson, 1 Mer. 405, 35 Eng. Rep. 723 (Ch. 1816), discussed in note 103 supra. See also discussion, note 11 supra. 
to rely on his own earlier pronouncement in Nickolson $v$. Knowles that an agent may not interplead his principal, adding that lie was "not aware of any instance of a bill of interpleader being sustained by a private agent."112 The proposition that an agent cannot interplead his principal liad now been advanced at two points, and two points are all that is needed for a line of autlority.

The transaction involved in Cooper v. De Tastet remained in litigation and occasioned a further doctrinal exegesis, this time by Lord Brougham in Pearson v. Cardon. ${ }^{113}$ As the facts unfolded, it appeared-as it had not appeared earlier - that $B$, in whose name the goods liad been originally deposited with the warelrouseman, was a partnership; that the order to transfer the goods to the third party $D$ liad been sent on the partnership letterliead by a dissident partner seeking to clean out the assets; that the countermanding order was by the managing partner seeking to undo the mischief; and that the warehouseman was thus caught in an internal battle between partners.

Brougham affirmed that it was a general rule that an agent could not interplead lis principal, for otherwise "an agent may at any moment treat his principal to a Cliancery suit."114 $\mathrm{He}$ then, lowever, evaded this new general rule by suggesting that in the case before him the partnerslip had sanctioned the transfer of the wool to the third party, so that the wareliouseman had been relieved of his agency. As a consequence, he said, "the paramount clain of [the transferee], and the mesne clain of [the partnerslip] coming into competition, a fit case for a bill of interpleader is raised."115 And so he sustained the bill. ${ }^{116}$

112 He managed to make this observation despite the fact that counsel for plaintiff cited Dowson v. Hardcastle, 2 Cox. 278, 30 Eng. Rep. 129 (Ch. 1791), and Edensor v. Roberts, 2 Cox. 280, 30 Eng. Rep. 130 (Ch. 1791), and could have cited a number of others. Furthermore, counsel argued that the warehouseman risked hability as a converter if he delivered to the wrong claimant, citing Stephens v. Elwall, 4 M.\&S. 259, 105 Eng. Rep. 830 (K.B. 1815), discussed note 106 supra. To this Leach replied that "the wool being deposited in a warehouse, the warehouseman becomes the agent of the principal, but if deposited in a bonded warehouse, the holder is the agent of the person entitled." This seems clearly to be both erroneous and irrelevant. It must have been quite an experience to argue before Vice Chancellor Leach.

1132 Russ. \& M. 606, 39 Eng. Rep. 525 (Ch. 1831).

114 Anyone acquainted with the cost and delay in Chancery at the time will appreciate that litigation in equity was no mean threat. But, of course, on this ground it would have been equally justified altogether to abolish interpleader, or Chancery itself for that matter. In any event, Brougham's threat-of-litigation argument is reminiscent of Hardwicke's similar suggestion a century earlier, and is similarly unpersuasive. See text following note 42 supra.

$115_{2}$ Russ. \& M. at 611,39 Eng. Rep. at 527.

$116 \mathrm{It}$ was in this opinion that Brougham made the startling pronouncement that "in looking at the rules of interpleader at law, you discover the principles that govern this Court [of equity]; because I hold it to be strictly a concurrent jurisdiction, and that you can have no interpleader here, if upon principle you could not have it at law." 2 Russ. \& $M$. at 613, 39 Eng. Rep. at 528. 
The first branch of Brougham's argument is question-begging, while the second is absurd. The rule that an agent may not interplead his principal in reference to a case such as Pearson v. Cardon is questionbegging because the question in such a case is whether the stakeholder continues to hold the goods as agent for the person who originally delivered them or now holds them on behalf of a transferee of the principal or some otherwise superior claimant. ${ }^{117}$ The other branch of his argument, the attempt to get around the rule he had just stated, was that the third party had received a "paramount title" which conflicted with the "mesne title" of the partnership. But the third party's "paramount title" could have derived only from the transfer of the goods that was in dispute and which the partnership, so far from "sanctioning," was fighting to set aside. Brougham's hittle shell game about "paramount title" nevertheless had the effect of adding fresh support to the idea about derivative title that had originated in Dungey $v$. Angove, ${ }^{118}$ and of adding weight to the idea that an agent cannot interplead his principal.

Despite this weight, the rule was shrugged off in no less than three cases decided in the next three years. One involved a bailee of goods; ${ }^{110}$ the other two concerned agents holding funds in escrow. ${ }^{120}$ But another warehouseman's case came up shortly in which the rule was not only applied but embroidered. This was Crawshay $v$. Thornton ${ }^{121}$ in which sprang forth the notion that the plaintiff in interpleader must not be subject to an "independent hability" to one of the claimants.

The plaintiffs in Crazeshay were a partnership in the business of wharfinger and warehouseman with whom a quantity of iron was deposited by Raikes \& Company, apparently a trader in iron and other commodities. Thereafter Raikes gave plaintiff an order to transfer the iron to Thornton, which plaintiff compled with by entering Thornton's name in its own inventory book and by writing Thornton a letter stating the iron was being held for his account. Raikes subsequently became

117 As was ohserved in Suart v. Welch, 4 Myl. \& Cr. 305, 41 Eng. Rep. 119 (Ch. 1839), the question is "who the principal for whom the party seeking the protection of an interpleading suit ought to be considered as agent." Indeed, the only way the proposition can escape begging the question is if the assumption is introduced that a warehouseman who is once an "agent" is always an "agent." But if he were to remain an "agent" for the person making delivery even after receiving the goods, no legal transfer of the goods could be made except by physically removing them from the warehouseman's custody. This would, of course, defeat the convement function that warehousemen were performing for a trading nation.

118 See text accompanying note 76 supra.

110 Mason v. Hamilton, 5 Sim. 19, 58 Eng. Rep. 245 (Ch. 1831).

120 Smith v. Hammond, 6 Sim. 10, 58 Eng. Rep. 498 (Ch. 1833); Moore v. Usher, 7 Sim. 383, 58 Eng. Rep. 884 ( $\mathrm{Ch} .1835$ ). In the former case, it was observed that "the proposition in Nickolson v. Knowles seems to be laid down rather widely."

1212 Myl. \& Cr. 1, 40 Eng. Rep. 541 (Ch. 1837). 
bankrupt, and plaintiff shortly thereafter received a letter from one Daniloff, of St. Petersburg, Russia. Daniloff stated that he was the owner of the iron, that Raikes had been his agent for its sale, that Raikes had without authority pledged the iron to Thornton and that the transfer of the iron to Thornton was therefore void. Daniloff demanded the iron and sued plaintiff in trover. Thornton, who no doubt had advanced money to Raikes on the strength of the pledge, was also adamant and also sued plaintiff in trover. Plaintiff filed a bill of interpleader.

The argument in opposition to the bill consisted of two points. First, "a tenant cannot dispute the title of his landlord, and so likewise an agent or servant who holds personal property belonging to his principal or master cannot dispute his principal's or his master's title." ${ }^{122}$ Second, plaintiff became "personally liable to Thornton by their letter [to Thornton] ... and the question will be, whether that letter amounts to a contract." ${ }^{\prime 23}$ Plaintiff cited cases to show that a warehouseman may refuse to surrender goods to the depositor when confronted with a third party claim, ${ }^{124}$ and that a warehouseman might interplead. ${ }^{125} \mathrm{He}$ apparently did not grasp, and certainly did not meet, the defendant's argument that plaintiff by the letter had made himself hable to Thornton for the value of the iron regardless of its ownership. And it was this argument that the court embraced, or, more accurately, that embraced the court. Chancellor Cottenham went right for it.

The case ... ought to be, that the whole of the rights claimed by the Defendants may be properly determined by litigation between them, and that the Plaintiffs are not under any liabilities to either of the

1222 Myl. \& Cr. at 11, 40 Eng. Rep. at 545.

1232 Myl. \& Cr. at 6, 40 Eng. Rep. at 543. The quotation is actually plaintiff's paraphrase of defendant's argument. By accepting the defendant's statement of the issue plaintiff went a long way to cutting his own throat.

Defendant used the plaintiff's letter to Thornton as a predicate for arguing also that plaintiff was not "an indifferent and an innocent stakeholder; ... he cannot file a bill of interpleader against a person with respect to whom he has put himself in such a position as to preclude him from disputing that person's title." 2 Myl. \& Cr. at 11, 40 Eng. Rep. at 545. The rule that plaintiff must be a perfectly neutral and disinterested stakeholder is one we shall come to presently. See text accompanying note 135 infra. The point of interest here is that the same out-of-court event was used as a platform for two formulations of objection to the interpleader, suggesting that the formulae were redundant, which certainly seems to be the case.

124 Ogle v. Atkinson, 5 Taun. 759, 128 Eng. Rep. 890 (Ch. 1814); Cotter v. Bank of England, 3 M. \& S. 180 (Ch. 1833). See also note 106 supra and note 131 infra.

125 Plaintiff relied chiefly on Langston v. Boylston, 2 Ves. Jr. 101, 30 Eng. Rep. 543 (Ch. 1793), discussed at text accompanying note 63 supra. He also drew on the distinction that had been made in Cooper $v$. DeTastet between a bonded warchouseman, who it was said could interplead, and an unbonded one, who could not. See note 112 supra. Plaintiff in Crawshay v. Thornton was bonded, if that should make a difference in any case, but it did him no good. 
Defendants beyond those which arise from the title to the property in contest; because if the Plaintiffs have come under a personal obligation, independently of the question of property, so that either of the Defendants may recover against them at law ... no litigation between the Defendants can ascertain their respective rights against the Plaintiffs. . . . 120

The first point to be observed is that the propelling force behind the court's reasoming is the concern to get a complete determination of the controversy in the one trial at law between the defendants. ${ }^{127}$ This concern no doubt stemmed from the fact that the established method of adjudicating an interpleader was to formulate an issue as between the two defendant claimants which would then be remanded to the law courts for trial to a jury. ${ }^{128}$ If there were a prehminary or collateral question as between the plaintiff and one or both of the defendants, it would be impossible to fit it into a common law framework for submission to a verdict. ${ }^{120}$ It seems not to have occurred to Lord Cottenham that he might send out two issues for trial, one to determine the ownership of the iron-a routine interpleader between the claimants-and the other to determine whether plaintiff was obligated to Thornton by virtue of the letter to him. What Lord Cottenham was unhappy about, and what in part caused him to invent the rule about "independent liability," was the fact that he could not reduce two questions to one question. It is an odd way of escaping this difficulty to refuse to decide either, but that was Lord Cottenham's way out.

The second point to be observed is that the possibility of an independent liability in favor of one of the claimants against the stakeholder is surely a fatuous reason for refusing the interpleader. Suppose the circumstances of that liability to lave been truly independent, for example that on another occasion entirely Crawshay had punched Thornton in the nose, or taken his watch. Such a misdeed would, of course, create a liability of Crawshay in favor of Thornton that would be independent of the squabble with Daniloff, and which could not be resolved in a suit between Thornton and Daniloff over the title to the iron. But what of that? Why should this preclude the interpleader of the iron? It seems

1262 Myl. \& Cr. at 19, 40 Eng. Rep. at 548.

127 The anxiety about completeness had caused difficulty before. See Hazard, supra note 18 , at 1271 .

128 See note 38 supra.

129 Thus the common law forms of action confined not only the scope of an action at law but also, in this instance at least, the scope of a suit in equity where issues of fact bad to be resolved. It seems quite possible that it was this problem that also explains the rule that the plaintiff must be "perfectly neutral" and claim no interest in the fund. See text accompanying note 135 infra. It is intriguing to speculate whether this procedural squeeze pinched equity at other points. 
unmistakably clear that an "independent liability" of the stakeliolder to one of the claimants has nothing to do with the matter, and that the choice of these words only added another misleading corollary to the already overburdened rules of interpleader. Quite the contrary, the reason why the letter from Crawshay to Thornton had significance was not because it was of "independent" legal significance, but because its import and legal effect were entirely dependent on the question of title to the iron.

On this relationship Cottenham was totally and irretrievably confused. Having got it into lis head, as we have seen, that the plaintiff might have "come under a personal obligation [to Thornton], independently of the question of property [in the iron]," he went on to explain how this surprising result might come about:

[T] he dealings of the Plaintiff with Mr. Thornton would be evidence for him in his action [of trover]. Suppose then that those acts, the transferring the iron into [Thornton's] name in the Plaintiff's books, and the letter ... should be held sufficient to procure for Mr. Thornton a judgment in his action, without inquiring whether Messrs. Raikes had or had not a legal right to exercise dominion over the property as they did. . . ..$^{\mathbf{1 3 0}}$

What could the book entry and the letter evidence? They would not go to show that warehouseman Crawshay had bought goods for Thornton or promised to buy them or sold or promised to sell them to him, all of which could create a liability to Thornton for a quantity of iron of the type described. The book entry and the letters concerned no sucl transaction, for their only effect as Cottenham said was a "transferring the iron into [Thornton's] name," so that as between Raikes and Thornton property in the iron had passed to Thornton. This would not be a sufficient showing to sustain a recovery by Thornton against Crawshay, if it should appear that Raikes had no title in the first place, for Thornton could not in that case establish that it was "his" property which Crawshay was holding. ${ }^{131}$ And whether or not it was "his" property was the very question Crawsliay sought to interplead.

Cottenham seems to have had some glimmermg of this difficulty, for his statement goes only so far as to "suppose that those acts . . . slould be held sufficient...." One could as well suppose that the iron was owned both by Thornton and Daniloff and deny interpleader on account of that "independent hability." But if conjectures this wild be indulged it would be simpler to abandon the middleman to his fate in every instance. The

1302 Myl. \& Cr. at 20, 40 Eng. Rep. at 548.

131 It was a defense to conversion that plaintiff had no title. See Ogle v. Atkinson, 5 Taun. 759, 128 Eng. Rep. 890 (Ch. 1814). 
mirage of "independent liability" did this for Crawshay, and also gave to posterity an additional empty procedural category. ${ }^{192}$

Crawshay v. Thornton was noticed but not applied in a couple of subsequent decisions, ${ }^{133}$ and then seems to have faded out of fashion. It was nevertheless preserved by the text writers and comes to us through Pomeroy.

\section{2. "Interest in the Subject-Matter"}

So much for "independent liability." The remaining of Poineroy's four requirements is the one to the effect that the stakelolder must not clain an interest in the fund or dispute the extent of his liability. This question does not seein to have arisen in the earlier cases. ${ }^{134}$ It may be

132 It would prolong this already extended discussion of Crawsiay v. Thornton to go into the way in which Cottenham garbled the precedents, not only those of interpleader but also the cases, principally Hawes v. Watson, 2 B.\&C. 540, 107 Eng. Rep. 484 (K.B. 1824), dealing with the question of transfer of title of goods in the hands of a warehouseman. His difficulty with the latter, in brief, was that he could not see the difference between a warehouseman's trying to reverse a transfer of title of goods concededly owned in the first instance by the transferor, which was the situation in Hawes $v$. Watson, and a warehouseman's wondering whether the putative transferor had any title to transfer, which was the situation in Crawshay v. Thornton.

Just for good measure Cottenham undertook to explain the relation between the rules that a tenant could not interplead his landlord, that an agent could not interplead his principal, his new idea about "independent hability" and the old idea about the "same debt or duty": "It is familiarly said that there is no interpleader between landlord and tenant, or a principal and agent; but it will be found that ... this rule . . . is . . not so much an independent rule as a necessary consequence of the principle of all interpleading. In both these cases, rights and habilities exist between the parties, independent of the title to the property, or the debt or duty in question, and which may not depend upon the decision of the question of title." 2 Myl. \& Cr. at 20, 40 Eng. Rep. at 548. One who has followed the convolutions of doctrine we have attempted to narrate will no doubt be left brcathless by this passage.

For a modern rejection of the "independent hability" requirement, see, e.g., Oliver v. Humble Oil \& Refining Co., 225 F. Supp. 536 (E.D. La. 1963).

133 See Suart v. Welch, 4 Myl. \& Cr. 305, 41 Eng. Rep. 119 (Ch. 1839) (letter by stakeholder to one elaimant affirming that stakeholder held insurance proceeds for claimant's account held not to create an "independent hability" so as to preclude interpleader); Jew v. Wood, Cr. \& Ph. 185, 41 Eng. Rep. 461 (Ch. 1841) (tenant's payment of rent to a purported devisee of the landlord does not create an independent liabihity precluding the tenant from interpleading the devisee and the heir at law to determine to whom to pay the rent).

134 In Earl of Thanet v. Paterson, Barn. 247, 27 Eng. Rep. 632 (1738), discussed at text accompanying note 41 supra, the defendant copyhold tenants had disputed their obligation to pay the fine allegedly due on their lord's death, as well as questioning to whom it was payable. No suggestion was made that interpleader could not be made of a disputed obligation, but nothing much can be inferred from this silence. Aldridge v. Thompson, 2 Bro. C.C. 149, 29 Eng. Rep. 86 (Ch. 1787), discussed at text accompanying note 60 supra, probably involved a dispute over the amount, as well as the payee, of the obligation, but again there is no discussion of the problem in the case. Morgan v. Marsack, 2 Mer. 107, 35 E.R. 881 (Ch. 1816), involved one elaimant who claimed all of the fund and another who claimed only a part of it, but the stakeholder did not question that he was obligated to pay the whole amount, the proceeds of a hife insurance agreement, to someone. 
assumed that if one had asked in the eighteenth century what the rule was, the off-hand answer would have been that the plaintiff was supposed to admit his liability and then back out. But there was no authority on the point.

The question presented itself in the year 1824 in both England and in New York. Different answers were given, but so far as we have been able to determine no one until now seems to have noticed the fact. Concealing the difference, and perpetuated to account for it, was the idea that there were two kinds of interpleader: "simple" or "true" interpleader, where the stakeholder was not permitted to dispute his liability, and a "bill in the nature of interpleader," where he could. In fact, the dichotomy is an invention.

Coming to the English cases first, the question arose in Mitchell $v$. Hayne, ${ }^{135}$ where the plaintiff, an auctioneer holding the proceeds of sale, was confronted with a claim by the seller for remittance of the proceeds and by the buyer for rescission. Plaintiff alleged himself to be in doubt whether to return the proceeds to the buyer or to pay them over, less his commission, to the seller. Vice Chancellor Leach denied interpleader on the ground that inasinuch as plaintiff stood to gain his commission if the seller won but to lose it if the buyer did, plaintiff was not "wholly indifferent between the parties." Where Leach got this idea is by no means clear. ${ }^{136}$ At any rate it was endorsed in Moore $v$. Usher in $1835,{ }^{137}$ and came on down to the twentieth century as the rule that the stakeholder in interpleader may not dispute his liability. ${ }^{138}$

The idea that there was a bill in the nature of interpleader in whicl the stakeholder could dispute his hability has its genesis in three New York cases. The first was a suit by a taxpayer seeking to resist imposition of personal property taxes by two different counties, each of whicl claimed him as a resident. In Thomson $v$. Ebbets ${ }^{139}$ the plaintiff alleged that he lived five months a year in New York City and seven months a year in Rhinebeck, in Dutcliess County, and that the tax assessors of eacli had taxed his personal property on the ground that lie was a local

1352 Sim. \& St. 63, 57 Eng. Rep. 268 (Ch. 1824).

$136 \mathrm{He}$ cited no authority. Aldridge v. Mesner, 6 Ves. Jr. 418, 31 Eng. Rep. 1122 (Ch. 1801), involved an auctioneer and Stevenson v. Anderson, 2 Ve. \& B. 407, 35 Eng. Rep. 373 (Ch. 1814), involved an escrow agent, neither of whom acted gratuitiously we may assume, but nothing had been said about their fees.

Leach went on to say that "Plaintiff is not, therefore, an indifferent stakeholder, but has a personal question to maintain with [the buyer]." This sounds like the germ of the idea that blossomed into the "independent liability" rule announced in Crawshay v. Thornton. See text accompanying note 126 supra.

1377 Sim. 383, 58 Eng. Rep. 884 (Ch. 1835).

138 See, e.g., Texas v. Florida, 306 U.S. 398, 406-07 (1939).

139 Hopk. Ch. 272 (1824). 
resident. The amount assessed by one collector was 142 dollars, by the other 136 dollars. Plaintiff brought a suit against both for a determination of which county's tax he was obligated to pay. The objection of one of the defendant assessors to the propriety of interpleader was overruled. There was no mention of the plirase "bill in the nature of interpleader" nor discussion of the fact that different amounts were being claimed. The only case cited by Clancellor Sanford in support of his decision was Aldridge $v$. Thompson, ${ }^{140}$ which did not explicitly deal with the problem. ${ }^{141}$

Six years later, in Bedell v. Hoffman, ${ }^{142}$ Chancellor Walworth liad before him an interpleader suit in which a controversy arose as to whether the plaintiff-stakeliolder should be allowed his costs of suit. It was the contention of the defendant that plaintiff slould not be allowed costs because he liad disputed the amount due, whereas the theory of allowing the stakeholder his costs proceeded from the assumption tliat an innocent bystander is entitled to imdemnification against expenses lie has incurred through no fault of his own. In response, the Cliancellor said:

A bill of interpleader strictly so called is where the complainant claims no relief ... Mitchell $v$. Hayne. . . But a bill in the nature of a bill of interpleader to redeem and to be let into the possession of mortgaged premises may be filed ... Goodrich v. Shoebolt, Prec. Ch. 333. ....143

This is a most peculiar statement. It was of course true that Mitchell v. Hayne ${ }^{144}$ liad lield that the stakeholder could not claim relief, i.e., dispute with the defendants as to the amount owing. But it had not previously been suggested that this was true only in "interpleader strictly so called," for no difference had ever been drawn between interpleader "strictly so called" and any other kind. Walworth's reference to Goodrich v. Shoebolt is even more puzzling. It seems evident that his reference was to Goodrick $v$. Shotbolt. ${ }^{145}$ That case did involve a bill of interpleader to redeem by a mortgagor in doubt as to whom to pay off the debt; and in that case the plirase "bill in the nature of interpleader" was used. But the fact that the bill was by a mortgagor seems to liave no relevance to the question whether the stakeholder may dispute the

1402 Bro. C.C. 149, 29 Eng. Rep. 86 (Ch. 1787). Sanford referred to it as Aldridge v. Williams, but the citation is unmistakable.

141 See note 134 supra.

1422 Pai. 199 (Ch. 1830).

143 Id. at 200.

1442 Sim. \& St. 63, 57 Eng. Rep. 268 (Ch. 1824), supra note 135.

145 Prec. Ch. 333, 24 Eng. Rep. 157; Gilb. Rep. 18, 25 Eng. Rep. 13 (1712). This is probably the same case as that referred to as Shotbolt v. Biscow, 2 Eq. Cas. Abr. 173, 22 Eng. Rep. 148; see note 21 supra. 
amount of his liability. And in Goodrick the report states that the amount due was agreed upon by all parties. ${ }^{146}$

At any rate, from these dubious premises Walworth drew the conclusion that there were two kinds of bills, strict bills and bills in the nature of interpleader. And, to dispose of the question before him, he ruled that in strict bills of interpleader plamtiff was entitled to his costs as a matter of course, while in bills in the nature of interpleader costs to the stakeholder were in the discretion of the court.

In the third case, also decided by Walworth, the ingredients in Thomson v. Ebbets and Bedell v. Hoffman were blended together. The case, Moharek \& Hudson R.R. v. Clute, ${ }^{147}$ involved essentially the same problem as Thomson v. Ebbets, a taxpayer seeking to interplead taxing offcials who lad made overlapping assessments on its property. One of the defendants in Mohawk objected that inasmuch as the plamtiff was disputing the amount of his liability, he could not maintain interpleader, citing Mitchell v. Hayne and other cases English and American. The court conceded that Mitchell v. Hayne sustained defendant's contention, but also observed that in Thomson v. Ebbets a similar objection had been overruled. To reconcile these seemingly irreconcilable precedents, Walwortl resorted to the distinction lie liad made in Bedell v. Hoffman: While it was true that the stakeholder could not dispute his hability in a simple bill of interpleader, as in Mitchell $v$. Hayne, there are proceedings where plaintiff "may file a bill, in the nature of a bill of interpleader, and for rehef, against both of the claimants. ${ }^{148} \mathrm{He}$ thereupon overruled the objection.

Story rearranged and generalized Walworth's statement into the following:

But although a bill of interpleader, strictly so called, lies only, where the party applying claims no interest in the subject-matter; yet there are many cases where a bill, in the nature of interpleader, will lie by a party in interest, to ascertain and establish his own rights, where there are other conflicting rights between third persons. ${ }^{140}$

140 Indeed, it seems evident that it was because the plaintiff mortgagor sought-in connection with his suit to redeem-a determination of whom to pay that the bill, which otherwise would have been an ordinary bill to redeem, was referred to a "bill in the nature of interpleader." The report, Prec. Ch. at 334, 24 Eng. Rep. at 158, says: "It was agreed on all hands that the plaintiff ought to redeem on payment of the $£ 200$ only ... and therefore this bill was in the nature of an interpleading bill, that they [the defendants] might settle the right between themselves. ...."

1474 Pai. 384 (Ch. 1834).

148 Id. at 393.

1492 Story, Equity Jurisprudence $\$ 824$ (1st ed. 1836). See Chafee, Cases on EquiTABLE REMEDIES 75-76 (1938), containing materials on "bills in the nature of interpleader." It may be noted that all of the cases Professor Chafee cites are American save one, Blyth v. Whiffin, 27 L.T. 330 (1872), and in that case the court relied on Story.

Story's synthesis is one of many efforts in his treatise to paper over cracks. 
And there we have two kinds of interpleader bill where one grew before.

This concludes the historical phase of our account. The congeries of rules, corollaries and exceptions that had piled up in the cases were carried forward substantially intact by Eden ${ }^{150}$ from whom they passed to Story, ${ }^{151}$ to Pomeroy, and to us. ${ }^{152} \mathrm{~A}$ curious sidelight is David Dudley Field's disposition of interpleader in his 1848 New York Code. Field's general plan for merging law and equity procedure into a single system required making some pretty strange marriages of convenience between cognate legal and equitable concepts. ${ }^{163}$ Such a marriage was celebrated with interpleader. ${ }^{154}$ What Field apparently did was to take from common law the rule that interpleader was a remedy available to a defendant, ${ }^{165}$ and froin equity the idea that the remedy should not be bimited to claims to tangible personal property but should be available with respect to

150 EDEN, INJUNCTIONS (1st ed. 1822).

151 Story, Equity JuRusprudence $\S 805$ n.2 (4th ed, 1846): "Mr. Eden's valuable Treatise on Injunctions contains a head of Interpleader, which I have consulted with great advantage, and have freely used. Eden on Injunct. p. 335 to $347 . "$ The reference is quite ap. parently to Eden's first edition, for the second edition came out in 1839, after Story's first edition in 1838 , and is differently paginated.

152 There can be little doubt that Pomeroy deserves chief credit, if that is the right word, for the four-fold system of "requirements" for interpleader. We have found no prior treatment that did inore than try to make patch-work sense out of the cases. Story tried to subject the decisions to some sort of conceptual discipline but it was not a thorough-going effort.

For a modern bout with Pomeroy, see Hopkins v. Hancock Oil Co., 24 C.2d 497, 150 P.2d 463 (1944).

153 See Louiseil \& Hazard, Pleadinc and Procedure, State aNd Federal 555-56 (1962).

154 The provision was not called interpleader, and it appeared as the second paragrapl of a rule covering necessary parties and intervention. The whole section, N.Y. Laws 1851, ch. 479, \& 122:

The court may determine any controversy hetween the parties before it, when it can be done without prejudice to the rights of others, or by saving their rights, but when a complete determination of the controversy cannot be had without the presence of other parties, the court must cause them to be brought in. And when, in an action for the recovery of real or personal property, a person, not a party to the action, but having an interest in the subject thereof, makes application to the court, to be made a party, it may order him to be brought in by the proper amendment.

$A$ defendant, against whom an action is pending upon a contract, or for specific, real, or personal property, may at any time before answer, upon affidavit, that a person not a party to the action, and without collusion with him, makes against him a demand for the same debt, or property, upon due notice to such person, and the adverse party apply to the court for an order to substitute such person in his place, and discharge him from liability to either party on his depositing in court the amount of the debt, or delivering the property, or its value, to such persons as the court may direct; and the court may, in its discretion, make the order. [Emphasis added.]

155 See text accompanying note 9 supra. 
claims against a fund as well. This arrangement had the effect of freezing into statutory form the half-truth that the claims in interpleader must relate to the "same" fund or "thing," with the attendant difficulties already suggested. ${ }^{150}$ It also had the effect of precluding by implication the initiation of interpleader by a plaintiff, for the new and supposedly comprehensive code of procedure did not say anythmg about sucli a suit. $^{157}$

There is no reason to believe that Field appreciated that he was constricting the scope of interpleader for a defendant and abolishing it altogether for a plaintiff; both consequences seem more probably the product of a drafting blunder. In any case, codification pretty well put beyond reach the possibility that the rules of interpleader might be reformed by judicial reassessment, even in the unlikely event that the courts of the Victorian era might have been so disposed. As it was, the Georgian coinplex of interpleader rules passed almost intact into the twentieth century. ${ }^{158}$

\section{III}

\section{CRITIQUE AND REFORMULATION}

The foregoing historical review has demonstrated to what we hope is a sufficient degree of satisfaction that:

1. The "classic" requirements for interpleader are not in any proper sense classic but in fact are of fairly late origin in the history of equitable jurisdiction.

2. The four requirements for interpleader stated by Pomeroy originated as improvisations $a d$ hoc and achieved generalization and authority by virtue of credulous extensions of precedent.

3. Of the four requirements, one-the requirement that the claimants' titles be "derivative" or from a "common source"-is plainly insupportable; another-the requirement that the stakeholder not dispute the extent of his hability-is the subject of

150 See text accompanying notes 93-95 supra.

157 See, e.g., Note, 6 Stan. L. Rev. 146 (1953). There was of course no rule that precluded a defendant in a Chancery suit from filing a cross-bill for interpleader in appropriate circumstances and there is at least one reported case where this was done. See Earl of Thanet v. Paterson, Barn. 247, 27 Eng. Rep. 632 (1738). But this was unusual because the stakeholder usually found himself sued first at law rather than in equity and would therefore appear in Chancery as a plaintiff seeking to obtain a stay of the legal proceedings to the end that he might interplead.

158 The English began the process of chipping away at the interpleader requirements as early as the Common Law Procedure Act of 1860, 23 \& 24 Vict., c. 126, § 12 (1860). See Attenborough v. London and St. Katherine's Dock Co., 3 C.P.D. 450 (1878), especially for the effect of the statute on Crawshay v. Thornton, 2 Myl. \& Cr. 1, 40 Eng. Rep. 541 (Ch. 1837). 
divided authority concealed by the suppositious "bill in the nature of interpleader"; another - that the stakeholder have no "independent liability" to either claimant-was a response to a now obsolete procedural difficulty; and the remaining one-that the claims relate to the "same debt or duty"-is question-begging.

And so, as we indicated at the outset, a fresh start is in order.

\section{A. The Basic Model}

We may begin by reflecting on the simplest case, that of a holder of a tangible object of personal property confronted with two claimants who demand it.

The stakeholder in such a situation has a dilemma, as we quickly recognize. He seems to deserve a procedural device by which to escape. It does not follow as quickly as might be supposed that the stakeholder should have a remedy. In fact, there are similar predicaments from which the law does not provide an escape. A debtor has no procedure to which he can resort-short of bankruptcy-to determine which creditor to pay now and which to pay later, though a conscientious debtor would surely feel anxiety about the fairness of a choice he might make in such circumstances. A testator might wonder what distribution of his estate would be appropriate between his favorite charities and his favorite heirs, but even for agonizing indecision there is not supplied a judicial remedy in such case. And if joint owners of a chattel bailed it together, the bailee would be left to choose for himself to whom redelivery should be made even though he feared the one might be disposed to cheat the other. The small but essential point to be made in offering these illustrations is that it is not the existence of a dilemma before the stakeholder that is the basis of interpleader, for some persons holding stakes and in a dilemma are not granted the remedy, and we suppose quite properly so.

Nor is the threat of multiple litigation facing the stakeholder a sufficient basis for interpleader. Everyone theoretically stands subject to the threat of hitigation, even baseless litigation. The accident that one person becomes the target of simultaneous suits does not of itself justify the unusual procedure of drawing them all into one proceeding. Moreover, even if the suits relate to the same transaction, and there is a possibility that they might have inconsistent outcomes, we submit that the conditions would not exist that have impelled the interpleader remedy. Take the case of multiple suits by passengers against a railroad following a trainwreck. There would be a plurality of actions, in some sense asserting "the same claim," which render the railroad "doubly vexed" and in 
which the possibility exists that some would result in verdicts for and others against the plaintiffs. A case can be made that all such claims should be determined in a single proceeding, a case whose components include the conservation of judicial and party time and energy and the achievement of consistency in adjudication. Conservation of judicial and party resources is an economic objective that has weight, perhaps weight sufficient in the absence of seriously competing considerations to call decisively for reduction of multiparty claims to a single proceeding. Consistency in adjudication is a value of a somewhat different order. In part it is simply aesthetic, the quest for symmetry in the system's results. ${ }^{150}$ In more important part, the urge to consistency is one phase of the search for equality in treatment that is pervasive, if never fully realized, in a legal order. One way to conduce to similarity of result in similar cases is to decide them simultaneously before a single tribunal, ${ }^{100}$ which in fact occurs in interpleader.

Indeed, so weighty are the values of conservation of resources and consistency of result that they could be held to justify a simgle proceeding whenever it appears that several claims are asserted which could be decided inconsistently. Especially is this so contemporarily, when we have come to accept the idea of big lawsuits as routine if not the norm. ${ }^{161}$ And if one were to take the literal meaning of Federal Rule 22 as the essential definition of interpleader, this would be the stopping point of the inquiry, for that Rule says that interpleader may be had where the middleman "is or may be exposed to double or inultiple hability."162 This fornula fits all the interpleader cases fron the historical period we have surveyed and all the modern cases we can think of as well. It also fits squarely the railroad with the trainwreck, for the railroad is surely exposed in such a situation to "double or multiple liability." On this analysis the procedure of interpleader rests on no broader ground than other rules of permissive joinder: It is nothing more than an optional

150 This vlaue can of course be disparaged. We see no reason why it should be.

100 This does not guarantee similar treatment, for-putting aside corruption-it is always possible that the tribunal at the point of decision will perceive a difference between cases which at the outset appeared similar. Thus in our trainwreck illustration there could be evidence that the injury to one of the plaintiff passengers was attributable to his being drunk, which would justify exculpating the railroad in his case. And the possibility that some such evidence might be presented carries the possibility that the evidence would be erroneously assessed by the trier of fact. Hence, unless it is decided a priori that the cases are similar, there is no escape from the fact that the system as administered may yield inequalities no matter what procedural precautions are taken.

161 Compare Louisele \& HAZARD, op. cit. supra note 153, at 557, 675-76; cf. Neal and Goldberg, The Electrical Equipment Antitrust Cases: Novel Judicial Administration, 50 A.B.A.J. 621 (1964).

162 See note 1 supra. 
method by which claims involving common questions of fact or law may be disposed of with the economy of a single proceeding. ${ }^{103}$

Yet it seems safe to conjecture that few will find this a satisfying stopping place. ${ }^{104}$ At least in the simple case which is the model after which more complex ones have been developed-the case of the stakeholder of tangible property-there seems to be something more that is at issue. We submit that there is something more to interpleader, a deeper basis of concern about the middleman's position than considerations of economy and equahity. We shall now attempt to show it.

The principal point to be recognized is that the middleman does not simply confront a dilemma-the debtor with two creditors does thatnor does he simply face "double or multiple liability"-the railroad with the trainwreck is in that position. Rather, the middleman that interpleader seeks to help is a man facing a dilemma that is caused by the fact that the law (incipiently if not yet actually) is addressing him with conflicting commands. In the simple case of the stakeholder in possession of, say, a watch, if claimant $A$ and claimant $B$ each demand the watch, the stakeholder has a dilemma of a practical nature and perhaps a moral one as well. But if $A$ and then $B$ successfully establish in a court of law that they are each entitled to possession of the watch, and if no procedure exists for reconciling the results, the middleman is confronted with two commands one of which he must violate.

This is not only a grave matter, it is a subversion of the very basis of the legal order. It is intolerable that a legal system should come down at the point of application to tell someone that he has orders such that he cannot help but disobey. ${ }^{165}$ It is subversive of the legal order that this be done, for a social order that is not a police state requires general voluntary obedience to the rules and this in turn requires general, and certainly official, assent that the rules are to be taken seriously as binding obligations. ${ }^{166}$ It is impossible for them so to be taken if the only sensible response to official command is to laugh or cry or to fight or lie down.

It may seem melodramatic to find such fundamental political implications arising upon the occasion of the replevin of a watch. But large

163 Cf. FED. R. Crv. P. 20.

164 See National Cas. Co. v. Insurance Co. of North America, 230 F. Supp. 617 (N.D. Ohio 1964). No doubt it is also true that few will be found who would quarrel with the appropriateness of the language of Rule 22. This probably indicates nothing more than that since the first few exciting years after the promulgation of the Rules no one who has occasion to care-except students-has bothered to read them. Hence, it is perfectly possible for the Rules to read unmistakably in one sense and to be understood unreservedly in another.

105 See Hart, The Relations Between State and Federal Law, 54 CouUM. L. REv. 489 (1954); cf. Kafka, The Trial.

${ }^{166}$ See H. L. A. Hart, The Concept of Law passim (1961). 
political values have relevance in humdrum circumstances-indeed one might suggest that the political values are large in proportion to their relevance in humdrum circumstances as well as histrionic ones. The legal sovereign can tolerate a lot of sloppiness and a lot of error in its administration. It can even swallow the incongruities of reaching contradictory decisions on identical law and similar facts, as in the trainwreck situation. But it cannot even for a brief interval rest officially indifferent to the fact that on a particular occasion it was talking out of both sides of its mouth, and uttering a command that it knew it could not enforce.

\section{B. Variations from the Model}

The possibility of conflicting legal commands, it seems to us, is the basis for the archetype, the standard case, of interpleader. The next step is to consider variations from the model. The first variation is presented if we suppose that one of the two claimants would be denied the remedy of restitution of the object and be given compensatory damages in lieu. In this variation there is no obstacle to enforcing both orders, for the middleman though he cannot in material fact give the watch to both $A$ and $B$ nevertheless can give it to $A$ and reach in his pocket for money of equal value to pay $B$. The extremity of contradictory legal orders is avoided, and so the case for interpleader in this situation is not quite so compelling.

Surely, however, it is compelling enough. The damages remedy afforded $B$ is intelligible only if it is understood as a compensatory substitute for actual restitution of the watch. The reason why the substitution is necessary is because the law with the other hand had directed that the watch be given to $A$. Since it cannot be given to both, the middleman is compelled to put up his own money as compensation to $B$ for an injury that the law ordered him to commit. This is little different from an expropriation of the middleman's property, and we should suppose on that account is a proper case for interpleader. ${ }^{167}$ Yet that case is the

107 It is of course true that the legal command to give the watch to $A$ would have been predicated on a factual and legal determination justifying the order, e.g., a finding that the watch was $A^{\prime}$ 's property. But such a determination is not ultimate truth in any sense. It is only "legal" or "administrative" truth, i.e., a determination which by established constitutional and procedural conventions is a sufficient basis for a final legal judgment. An equally regular and final determination was made that the watch was $B$ 's. These determinations could be regarded as consistent only if the law's constitutional and procedural conventions were treated as the sole frame of reference by which to assess their validity and accuracy. But the formal conventions of the law are not our only frame of reference, at least in the skeptical modern West. We should also apply the frame of reference of common sense and take notice of the fact that there was indeed only one watch, which could not be owned by both $A$ and $B$-if "own" is used consistently. Hence, standing outside the law's formal frame of reference we would notice that it would be unjust, though it would have 
very one in which application of the "same debt or duty" rule, whose origin we have already traced, could preclude the remedy. It could be said-indeed it was said in Dungey $v$. Angove and cases following itthat in such a case $A$ claims the watch while $B$ claims only money, and hence they claim different things. This only demonstrates, it seems to us, how far from the heart of the problem one can go by following that formula. ${ }^{168}$

The next variation from the original model is to suppose that the claims of $A$ and $B$ relate not to a tangible object but to an obligation on the part of the middleman. The simplest case is where the middleman comes under obligation to $A$ and then $B$ suggests that on account of some dealing between $B$ and $A$, the middleman's obligation is now due $B$. This is the case, for example, of an insurance annuity in favor of $A$ the proceeds of which allegedly have been assigned by $A$ to $B .{ }^{160}$ This case is in many respects like that of the watch, just previously considered, but there is no tangible object on which we can keep our eye, and this makes it easy to omit an important step in the process by which the obligation is assimilated to a tangible object. Failure to recognize that this step is involved, it seems to us, has led to much confusion.

The point in short is that the middleman's obligation can be thought of as a thing over which the claimants are fighting-that is, it can be assimilated to a tangible object-only if both claimants contend that their respective rights against the middleman originate in an identical legally significant event. We may take the insurance annuity case as an illustration. If claimant $A$ asserted that he was entitled to 2000 dollars from the insurance company because policy no. 1234 in that amount had been issued in due form and the annuity period had matured, etc., while claimant $B$ asserted he was entitled to 2000 dollars due on policy no. 1235 , we should not assimilate the situation to that where $A$ and $B$ seek the saine watch. We might say that $A$ and $B$ claimed the "same thing," but we would mean by this only that their claims were of similar type and equal amount. We can properly treat the obligation as $a$ thing similar to $a$ watch only if $A$ and $B$ each affirms that (1) he claims on a policy in the amount of 2000 dollars, and (2) there is only one such policy, and (3) that policy is no. 1234 .

If the assertions of $A$ and $B$ do not have this congruence, it is possible

been formally lawful, to compel the middleman to make compensation to $B$. And it seems not too strong to call the injustice an expropriation.

168 This, of course, is what happened in Crawshay v. Thornton, 2 Myl. \& Cr., 40 Eng. Rep. 541 (Ch. 1837), discussed at text accompanying note 121 supra. Compare the careful analysis in Baron Bros. Co. v. Stewart, 182 F. Supp. 893 (S.D.N.Y. 1960).

${ }^{169}$ See, e.g., New York Life Ins. Co. v. Dunlevy, 241 U.S. 518 (1916). This case is generally thought of as a garnishment case, which of course it was also. 
that each is claiming on a different policy. If their claims are similar in the respects (1) and (2) just mentioned but not (3), the claims are similar and may relate to the same policy. But it is also possible that even though $A$ and $B$ each thinks there is only one pohicy, in fact they have in mind different pohicies. Only if they each identify a single obligation-creating event as the predicate of their clain can we safely speak of there being one obligation. ${ }^{170}$ Both $A$ and $B$ have to contend congruently before we may safely assimilate the case to that where the claims relate to a single tangible object.

On this analysis the propriety of interpleader is dependent on the contentions of the claimants. Put another way, it follows that the middleman's procedural right to obtain interpleader depends in effect on whether his adversaries have stipulated a crucial fact. This is true unless, as we shall see presently, an alternative method exists for establishing that the claimants are indeed seeking the "saine thing." It may seein peculiar that the propriety of interpleader can rest on the fact that there is an agreement between the contending claimants, but agreement between them is by no means impossible or even unusual. A new insurance policy-or a new warehouse receipt or a new marketable title to rental premises-cannot be invented out of thin air even by the most credible liar. Claimants with similar claims are often found on common factual ground at a key point or points in their claims, and when they are we may say the middleman has one obligation.

When the clainants start from this kind of common ground, the case is a proper one for interpleader. In sucli a case we may justifiably assimilate the iniddleman's obligation to a thing and grant interpleader for the same reasons that support interpleading of claims to a watch. Unless there is a proceeding in whicl the inconsistent affirmations of $A$ and $B$ can be resolved consistently, the middleman stands to suffer an expropriation.

Indeed, for just this reason interpleader in such a situation was held to be not merely appropriate but obligatory under the due process

170 Even this position is not absolutely secure. If the claimants could freely change their contentions prior to verdict, it would be impossible to determine prior to verdict whether there was one obligation-policy no. 1234-or perhaps two, one of the claimants having suddenly made this contention. Theoretically, therefore, it could not be firmly establisired that there was one obligation until the time for amending contentions had ended, and this is after verdict under rule systems such as the Federal Rules. See FED. R. Crv. P. (15). But triers of fact are notoriously and rightly skeptical of claimants who shift ground and so the claimants' fear of loss-usually reenforced by a moral concern for telling the truth-provides a practical guarantee that they will in most instances stand still on their contentions. This permits us to say that there is one obligation and hence to treat the case as a proper one for interpleader. There are still other dimensions to this problem that need not be explored here. 
clause. This was in the recent decision in Western Union Telegraph Co. v. Pennsylvania. ${ }^{171}$ The Commonwealth of Pennsylvania brought an escheat proceeding to recover sums deposited with the telegraph company for transmission as money orders. The sums in question had gone uncollected by the addressees and unreclaimed by the senders. It was held that Pennsylvania could not hold the company liable for these sums in the face of proceedings by New York (and other states) to recover the same amounts, for this would subject the company to the risk of having to pay twice and thus deprive it of its property. The State of New York could not be made party to the Pennsylvania proceedings, on account of sovereign immunity, nor Pennsylvania a party to New York proceedings, so neither state could enter a judgment that would acquit the company against the claim of the other. The Supreme Court invited an original proceeding before it between the states, the company no doubt to be joined as a party. This amounts to interpleader. ${ }^{172}$

Two further points need to be made at this stage of the analysis. The first is that a proper case for interpleader is made when the claimants' claims are congruent (and inconsistent) in any material respect, and not merely when they are congruent in all respects. Indeed, it is strictly speaking impossible for the claims to be precisely the same, for each claimant at some point or other (in pleading or in proof) has to show what events occurred that entitle him rather than his rival to recover the object or obligation in question. A claim consists of a linked series of propositions which in conjunction are a legally recognized predicate for granting the claimant judicial rehef. ${ }^{173}$ At least one of the links will have to connect the particular claimant with the object or obligation, and this link differentiates the respective claims froin each other. It is therefore not merely unnecessary but impossible that the claims be entirely congruent. Moreover, if they are congruent as to any link, the reasons supporting the interpleader remedy are as equally relevant as when several links are congruent. The risk is presented that the link that is common to both claims will be established inconsistently if it is considered in separate proceedings.

This point can be simply illustrated in the fact situation that was presented in Dungey v. Angove in the eighteenth century and Hancock

171368 U.S. 71 (1961).

172 It is puzzling why Western Union has not received wider attention, for its implications surely transcend the escheat category into which most commentators have relegated it. Cf. Loutserx \& HAZARD, op. cit. supra note 153, at 429-31.

173 See Michael \& Adler, The Trial of an Issue of Fact, 34 Cosurs. L. REv. 1224, 1462 (1934); Cleary, Pleading and Presuming: An Essay on Juristic Immaturity, 12 Stan. L. REv. 5 (1959). 
Oil Co. v. Hopkins ${ }^{174}$ in the twentieth. In each case the middleman had leased the premises froin $A$, who held himself out as owner of the fee. Thereafter $B$ appeared, claiming himself the rightful owner of the property. $A$ 's claim against the tenant, embellished with a little pleading language for authenticity, would go something like this:

1. At all times material, $A$ was and is the owner of Blackacre;

2. On or about March 1 of the year —A leased Blackacre to Middleman, at a rental, etc.;

3. Middleman despite repeated demand refuses to pay the rent reserved; ${ }^{175}$

4. $A$ demands judgment for the rent. ${ }^{176}$

$B$ 's claim would go like this:

1. At all times material, $B$ was and is the owner of Blackacre;

2. On or about March 1 of the year —-, Middleman entered upon and occupied, and continues to occupy Blackacre;

3. Middleman despite repeated demand refuses to vacate Blackacre;

4. $B$ demands Middleman's ouster and damages for the trespass.

These claims are not "the same." They are congruent only in their respective propositions no. 1 . But the congruence of these single links is sufficient to create in full extent the risk which interpleader is designed to obviate, for if the issue involved in proposition no. 1 is decided inconsistently, Middleman may pay twice. It is therefore a proper case for interpleader. Indeed, if we have not read too much into the Western Union opinion, it is a case where interpleader is required under the fourteenth amendment. ${ }^{177}$

The second point to be mentioned at this stage is that the logic of interpleader is essentially the same as the logic of the necessary parties

17424 Cal. 2d 497, 150 P.2d 463 (1944).

${ }^{175} A$ could explain at this point that the tenant refuses to pay the rent because $B$ is claiming himself to be owner of the premises and the tenant is worried about paying twice. If $A$ initiated legal proceedings by suing for the rent, he would not allege this fact because, among other things, it would be surplusage in his complaint. It would of course be entirely appropriate in the middleman's complaint in interpleader.

176 In the alternative, $A$ might allege that the lease was terminated by reason of the non-payment of rent and seek to oust the tenant. This simply illustrates that the landlord has the alternative remedies of damages and restitution of the premises. To claim either remedy, $A$ would have to allege himself to be owner of the premises, however.

177 This is why it has been suggested that Western Union Telegraph Co. v. Pennsylvania, 368 U.S. 71 (1961), overruled New York Life Ins. Co. v. Dunlevy, 241 U.S. 518 (1916). See LOUISELI \& HAZARD, op. cit. supra note 153. 
rule. That rule, which appears in formulations of varying precision and felicity, ${ }^{178}$ requires that all persons be joined in a suit who ought to be parties if the court is to render a judgment that will dispose of the controversy without prejudice to the practical interests of persons concerned with the transaction in question. ${ }^{179}$ The necessary parties rule permits the court, on its own motion or at the suggestion of a party, to bring in the third person. In the typical necessary parties situation, the third person is a claimant of the property or obligation that is in suit. $\mathrm{He}$ is brought in so that the person holding the property or owing the obligation, ordinarily the defendant in the origmal suit, will not later be squeezed by an inconsistent adjudication. To use the nomenclature we have used so far, it is a case where $A$ sues Middleman and Middleman then demands that $B$ be brought in as a necessary party. ${ }^{180}$ Interpleader is a case where, relying on same considerations of fairness, Middleman mitiates the legal proceedings by joining $A$ and $B$ and demanding that they interplead. ${ }^{181}$ It may be added, finally, that intervention is likewise parallel in its logic: That is a case where $A$ sues Middleman and $B$ takes the initiative to enter the suit by applying for intervention. ${ }^{182}$ Three rules have grown where one could do.

We now may take a further step away from the model, one that carries us very nearly to the end of our journey. This is where the middleman has an obligation which under its terms he may discharge by paying

\footnotetext{
178 E.g., Fed. R. CIv. P. 19; CAL. Code Crv. Proc. § 389, N.Y.CPLR § 1001.

179 See Preliminary Draft of Proposed Amendments to the Rules of Civil Procedure for the United States District Courts, Part II 55-59, 34 F.R.D. 325, 379-83 (1964),

$180 \mathrm{~A}$ case that is classic in form and clarity is Woodcock v. Mayne (1676), in Nottingham's Chancery Cases, 73 Seld. Soc. 314 (No. 451) (Yale ed. 1957), described in Hazard, supra note 18, at 1258: "A junior encumbrancer brought a bill to require a prior mortgagee to redeem so that the junior encumbrancer could enforce his claim; the defendant objected, contending that the heir of the mortgagor should be made a party. In sustaining the objection, Nottingham reasoned:

[T] he heir of the mortgagor to whom the equity of redemption is descended is not made a party, so that either the account now to be now taken of what is due upon the mortgage will conclude the heir, or it will not. If it must conclude him, then 'tis fit the heir should be called in and made privy to it. If it will not conclude him, then the defendant will be in danger to account twice unless the heir be party. So either for the heir's sake or for the defendant's sake there is a necessity of amending this bill and making the heir a party.

181 If the common law action had not been so rigidly confined to a two-party model, a necessary parties rule could have been developed and applied in the common law courts to achieve the results that were obtained more circuitously by interpleader in equity. It would follow that the interpleader remedy would not have been needed except as a matter of convenience to middlemen to allow them to start the hitigation rather than having to await being sued.

182 Compare the early suggestion of this relationship in BoHUN, quoted at note 36 supra. We venture to suggest also that Western Union Telegraph $C_{o}$. v. Pennsylvania is equally relevant to the necessary parties rule, and may therefore elevate it to constitutional status. See Loutsetr \& HAZARD, op. cit. sutpra note 153, at 749.
} 
either $A$ or $B$. The simplest case is a promissory note payable jointly to $A$ and $B$ or to a partnership, where payment to any of the obligees is a performance discharging the obligation. A more complicated but modernly more important type of case is where a liabihty insurance carrier is confronted with claims against its insured that exceed the limits of the policy. ${ }^{183}$ In this type of case, the middleman does not face the risk of paying twice, for he is acquitted upon payment. ${ }^{184}$ There is a risk, however, that the members of the group may be treated disproportionately, for if the first to come forward is fully served, there may be nothing left for the tail-enders. It is unfair that a group similarly situated be treated dissimilarly, and especially that preference among them be shown to the hoggish. There is still more at stake in the typical case of the hability policy, for the claims in such a situation, being personal injury claims, are indeterminate in amount in advance of settlement or adjudication. Because settling one share cuts down the pie available for another, the settlement process easily breaks down into a circular interdependency. Interpleader invites supervision of settlement, and enhances the possibility that trials may be avoided to fix the shares.

The case for interpleader here certainly is not as strong as in the original model, nor even in the variations previously considered. There is neither the risk that the legal system will order the impossible, nor that its orders will by their inconsistency work an unjust exaction. The risk is that if the law stands aside and lets private dispositions proceed in their own way, someone who has a legal right on a par with anothera claim to a share - will be left empty-handed in the payout. It may well be inappropriate, indeed almost surely would be inappropriate, for the law to insist that the obligor in such a situation see to a fair-sharing as a condition to being discharged of his obligation. Interpleader accordingly slould not be required. But if the obligor is bothered by the prospect that he may work a disproportion if he proceeds by himself and if he on that account asks official aid to effect an equitable distribution of the proceeds of his obligation, it would seem that this is a sufficient case for interpleader. ${ }^{185}$

\section{The "First Stage" of Interpleader}

The basic model with which we began involved no question that the claimants were seeking "the same thing," a watch. The variations from

183 See Pan American Fire \& Cas. Co. v. Revere, 188 F. Supp. 474 (E.D. La. 1960).

184 There could exist, however, the risk, which may be ignored in the interests of simplicity, that he could not prove payment had been made. If this risk were serious, it would be a case of threatened double hability predicated on inconsistent propositions and therefore covered by the discussion already had.

${ }^{185}$ See, e.g., Commercial Union Ins. Co. v. Adams, 8 F.R. Serv. 2d 22.13, Case 2 (S.D. Ind. 1964); Pan American Fire \& Cas. Co. v. Revere, 188 F. Supp. 474 (E.D. La. 1960). 
the model were similar in that they all involved cases where the claims were "the same" in the qualified sense that they each contained at least one common link. It was suggested that the rationale of interpleader began with the fact that the claimants were thus in agreement on a key starting fact-that there was one watcl, or one insurance policy, etc., and that the particular claimant was entitled to it. And it was pointed out with respect to claims to intangibles that only if there was such an agreement could we properly think of there being a single obligation as the subject of conflicting claims.

The problem that then arises is this: What if the middleman contends that there is a single obligation but one or more of the claimants disagrees, and asserts that there are two (or more) obligations? The case is not one of which we can say at the point of beginning that there is a risk that the middleman may have unjustly to pay twice, because for all we know lie ought rightly to pay twice-there may indeed liave been two watches or two imsurance policies.

In the basic model it was established in advance of any adjudication, by the common assent of the parties, that there was a single predicate for the middleman's obligation to $A$ or to $B$. Where there is a dispute whetler there is a simgle predicate or multiple predicates, until this dispute is resolved it cannot be ascertained whether the middleman will have to pay twice and, if so, whether it will be unjust that he do so. In short, we cannot say whether it is a proper case for interpleader. ${ }^{186}$

In the absence of some sort of special procedures, the solution to this problem was fairly simple but not entirely satisfactory. The claims would proceed separately against the middleman, and he would defend one or both on the ground that the obligation sued on was owed to another. If lie succeeded in both defenses, he would have a windfall; if he succeeded in one, he would be relieved of the obligation to pay twice, whether justly so being another matter. If le lost both, it could be that justice had triumphed, for he might well have lad two obligations and simply been trying to play one off against the other. But it is also possible that in losing both he would have been made the victim of inconsistent dispositions.

The nub of the problem was the absence of any procedure to invite the trial tribunal to consider the possibility that the middleman was riglt in contending that there was only one obligation, however confused

186 A recognition of this difficulty undoubtedly gave force to the traditional proposition that the claimants' claims must relate to the "same debt" and seems also to underlie the rule that the middleman may not have an "independent liability" to either claimant. In this view the propositions that the clains must relate to the "same debt" and that there must be no "independent liability" are simply two different ways of saying the same thing. 
he might be as to whom he owed it. The evidence in the trial of one claim would not ordinarily be admissible in the trial of the other; the verdict in the first would never be admissible; and the proof-taking as a whole could not be exactly the same where in each trial one claimant was a party and the other at most only a witness. With these discrepancies between the hearings, the result could be reached in each case that there was only one claim but that it was due the plaintiff in the case at hand. ${ }^{\mathbf{1 8 7}}$

A solution is to provide a prehminary trial to determine whether the middleman's contention that he has only one obligation is well-founded. This is what Professor Chafee called the "first stage" of interpleader, though strictly speaking it would perhaps be more appropriate to call it a preliminary to interpleader. This is so because adjudication of the middleman's contention yields an established determination of the same fact that in the basic model of interpleader is provided by the parties' agreement, namely that there is a common predicate for the claims of both $A$ and $B$. Indeed, Professor Chafee's term may have invited a certain amount of confusion because it does not make clear the logical relation between (1) the determination of whether there is a common predicate to the two claims (the "first stage"), and (2) contingent upon the making of this determination, the interpleader itself. ${ }^{188}$ Moreover, in modern procedural systems the same solution could be reached by treating the middleman's contention as a proper case for a declaratory judgment ${ }^{189}$ or as a proper occasion for consolidation of two cases involving common issues of law and fact. ${ }^{190}$

Creating a prehminary stage for interpleader is, however, a workable solution, so long as its relationship to interpleader proper is kept in mind. What needs to be said here is only that the rationale supporting such a procedure is much weaker than that which underhes interpleader itself. The injustice it obviates is contingent, not certain. Moreover, even without the procedure the middleman has a fighting chance to escape by making a good defense to the actions by the claimants. But of course he has that chance without interpleader even in the case of the basic model: $\mathrm{He}$ might be successful in defending the replevins of the watch and,

187 It can be supposed that in the earlier days it was not much of a practical problem. $A$ jury from a small local panel under instructions of a judge trying both cases (quite possibly at the same term and even on the same day) was unlikely not to see the point.

188 See Brisacher v. Tracy-Collins Trust Co., 277 F.2d 519 (10th Cir. 1960). For an instance where there seems to lave been uncertainty in this respect, see Girard Trust Co. v. Vance, 5 F.R.D. 109 (E.D. Pa. 1946); cf. Builders and Developers Corp. v. Manassas Iron \& Steel Co., 208 F. Supp. 485 (D. Md. 1962).

189 See, e.g., 9A UNIFORM LAws ANN. 1 (Uniform Declaratory Judgments Act); Cat. CODE CIV. Proc. \$§ 1060-62(a).

190 See FEd. R. Crv. P. 42. 
indeed, wind up with a timepiece for himself. The Chancellors thought that chance was madequate in the model case and in consequence fashioned interpleader to help the middleman out of his predicament. That reasoning seems to carry far enough to justify a "first stage" for interpleader where the middleman contends that he has only one obligation.

Finally, we may give brief consideration to the situation where the middleman disputes the amount of his obligation, which long ago gave rise to the idea of a "bill $\mathrm{m}$ the nature of interpleader." This actually involves tacking on an additional preliminary inquiry, a pre-"first stage" hearing, and is covered in general by the analysis that has been already developed.

At its outer limit, this is the case where the plaintiff in interpleader denies that he owes anything at all, a middleman who in effect denies that there is anything of which he is in the middle. His request for interpleader is thus conditional on his losing an initial contention that he owes nothing. His next contention, which ordimarily follows a fortiori, is that if he owes anything, he only owes it once, i.e., the same contention made by the interpleader planitiff in the "first stage" that he has only one obligation. At this point the two situations are identical and the analysis heretofore applies. There is the difference that the middleman who disputes the amount of his liability does not present himself, hat in hand as it were, as a nice guy who only wants to do the right thing. But legal remedies are for the protection of the hard-headed as well as the softhearted and it is difficult to see why a man should be condemned to pay twice simply because he thinks he should not pay at all. A hearing can be held to determine whether he owes anything at all and, if so, how much. This would be a "pre-first stage," followed if appropriate by the "first stage" to determine whether there is one predicate for obligation or two, followed if appropriate by the interpleader itself. ${ }^{101}$

\section{CONCLUSION}

If we are correct in our analysis, the interpleader rule could be fornulated this way:

A person against whom two or inore persons make claim may bring an action for determmation whether he is liable to one or several of the claimants, and if so to what extent, whenever:

(a) the claims involve contentions of fact, or contentions of mixed law and fact, such that the plaintiff may sustain double

101 See, e.g., Walmac Co. v. Isaacs, 220 F.2d 108 (1st Cir. 1955). 
or multiple liability as a consequence of the contentions being determined inconsistently; or

(b) the claims may exhaust a limited fund to which the claimants look for recovery.

The accepted conception of interpleader is we believe covered by this formulation. It is also covered, we may add, by the more imclusive if more amorplous terms of the declaratory judgment rule. Those who prefer a more relaxed attitude towards procedural problems than these pages manifest will no doubt find that rule more comfortable. 